\title{
Winners and Losers in Customs Unions: An Experimental Investigation
}

\author{
Baboo M Nowbutsing \\ University of Mauritius, Reduit, Republic of Mauritius \\ b.nowbutsing@uom.ac.mu
}

\begin{abstract}
In the context of a Competitive Ricardian Model (CRM), one can ask whether it is possible to relate winners and losers from a CU based on comparative advantage considerations. This was pursued by Venables (2003), who showed that careful consideration of a country's comparative advantage - with the rest of the world relative to that with its partners in the CU- yields predictions about winners and losers. Starting from initial tariff equilibrium, in a 3 country model with a continuum of goods, he shows that a country with 'extreme' comparative advantage will be more vulnerable to trade diversion. In this experiment, the $3 \times 3$ Competitive Ricardian Model (CRM) in two scenarios multiple import tariffs and a customs union. We fully characterise the equilibrium under both. Starting from a tariff distorted situation, we find that when a customs union is formed there is an increase in trade flows among members; a rise in individual consumption of some goods; a clear terms of trade effect and the existence of trade diversion. Our experimental results support the simulation findings of Venables (2003), who showed that countries which have 'extreme' comparative advantage in a customs union will generally be more vulnerable to trade diversion.
\end{abstract}

Key words: Competitive Ricardian Model; Tariff Distorted Equilibrium; Custom Union Equilibrium;

\section{Introduction}

The growing literature in experimental economics shows that market convergence generalise to a wide class of experimental economies, including those with multiple markets, small as well as large numbers of traders, robot traders or human traders, and markets with externalities. Although experimental economies converge towards equilibrium predictions, this process is not immediate. Convergence is achieved through a dynamic process that leads the variables in the economy towards equilibrium values. As experimental economies become more complex, the attainment of equilibrium becomes slower and less comprehensive. However, the equilibration process interacts with the specific interdependencies in different microeconomic structures to produce consistent and replicable results. There are many authors who have studied different complex environments including market interdependencies. Examples include Goodfellow and Plott (1990), who include production with derived demand; Chen and Plott (2002), who induced an exchange economy with two or more commodities; Lian and Plott (1998) who induced a small general equilibrium system with a circular flow of income; Noussair et al (2007) who created a large experimental environment to represent 3 countries trading in a perfectly competitive world; and Noussair and Powell (2008), Noussair and Powell (2008) who constructed experimental markets to observe behaviour of assets markets that experience a peak or trough in fundamentals.

There are few experiments who addressed international trade issues. Noussair et al (1995) tried to answer questions related to the law of comparative advantage, factor price equalisation, terms of trade, efficiency in production and exchange as guided by multiple and interacting markets and the effects of tariffs on international transactions. Engelman and Normann (2003) analysed the model of strategic trade policy proposed by Brander and Spencer (1985). They created a Cournot duopoly framework, matching the requirements of the Brander and Spencer (1985) theory. Nowbutsing (2011) analyse the fragility of the law of the comparative advantage in higher dimensions in an experimental laboratory.

Viner (1950) famously argued that it is the relative strength of trade creation and trade diversion which determines whether or not a customs union (CU) will be beneficial or harmful. The former involves a shift in domestic consumption from a high-cost domestic source to a lower-cost partner source; the latter a shift from a low-cost domestic source to a higher-cost partner source. In the context of a Competitive Ricardian Model (CRM), one can ask whether it is possible to relate winners and losers from a CU based on comparative advantage considerations. This was pursued by Venables 
(2003), who showed that careful consideration of a country's comparative advantage - with the rest of the world relative to that with its partners in the CU- yields predictions about winners and losers. Starting from initial tariff equilibrium, in a 3 country model with a continuum of goods, he shows that a country with 'extreme' comparative advantage will be more vulnerable to trade diversion.

In this paper, the $3 \times 3$ CRM is explored in two scenarios: the existence of multiple import tariffs and formation of a customs union. Under the tariff distorted (TD) situation, each country imposes tariffs on its imports whereas in the customs union, two countries abolish import tariffs between themselves, while imposing a Common External Tariff (CET) on non-member countries. Clear-cut predictions about production, consumption, net exports and the terms of trade are made. The experiment features three countries which differ in their level of endowment and production technologies, three output goods and one factor. The laboratory environment allows the investigatation of several issues. First, does the theoretical model predict the outcome well when the formation of a custom union is allowed? Second, is there the existence of trade diversion? Third, does an extreme comparative advantage country lose from union membership? Starting from a tariff distorted situation, it is found that when a customs union is formed there is an increase in trade flows among members; a rise in individual consumption of some goods; a clear terms of trade effect and trade diversion. Therefore, the experimental results support the simulation findings of Venables (2003).

This research adds to the experimental trade literature in two ways. First, this is the first attempt to model customs union formation in a laboratory setting. Second, although much has been written on welfare comparisons of tariff- distorted and customs union equilibria in analytical and empirical models, this is the first attempt to address this using laboratory generated data. The remainder of the paper is structured as follows: Section 2 describes the experimental parameters. Section 3 presents the theoretical predictions of the TD and CU models. Section 4 describes the statistical methodology. The results are reported in Section 5. The conclusion is presented in section 6.

\section{Experimental Design}

Parameters: A generalized CRM with three countries and three goods motivates our environment. Trade in all markets followed the continuous double auction rules that were implemented through the MUDA software, details of which are available in Plott (1991) and Plott and Gray (1990). Table 1 shows the experimental parameters. We assume that continuous approximation of the utility functions of both consumers and producers are quadratic and additively separable ${ }^{1}$. The idea of separability is of fundamental importance. If utility is directly additive, then the marginal utility of any good varies with the quantity of that good alone. This representation of utility is also consistent with the goods being normal. In addition, given any income, the ratio of the income elasticity to its price elasticity is taken to be constant. In our case, it also makes it easy to determine redemption values of consumers. Each country has an equal number of producers and consumers and is endowed with a given amount of labour. Countries differ in their level of endowment and production technologies. Total endowment in each country is four times the amount listed in the table.

There are two types of agents/traders in each country: C and P. Furthermore agents are divided equally among countries ( 6 each) and each has an equal number of Type $C$ and $P$ ( 3 each). Labour (L) is immobile between countries, whereas $\mathrm{X}, \mathrm{Y}$ and $\mathrm{Z}$ can be traded wherever they are produced. The market system works as follows: Type $\mathrm{C}$ agents are owners of $\mathrm{L}$ and have induced preferences for consuming $\mathrm{X}, \mathrm{Y}$ and $\mathrm{Z}$. So they sell $\mathrm{L}$ to Type $\mathrm{P}$ agents in their respective country and buy units of $\mathrm{X}, \mathrm{Y}$ and $\mathrm{Z}$ from any countries. $\mathrm{P}$ agents are also endowed with $\mathrm{L}$ (a smaller amount compared to $\mathrm{C}$ traders) and buy $\mathrm{L}$ from $\mathrm{C}$ in their own countries. They use it to produce $\mathrm{X}, \mathrm{Y}$ and $\mathrm{Z}$, according to their respective production schedule, which they sell to consumers in all three countries. $C$ traders gain utility from consumption of goods $\mathrm{X}, \mathrm{Y}$ and $\mathrm{Z}$ and from profits made in market activities and speculation. Any units of $\mathrm{X}, \mathrm{Y}$ and $\mathrm{Z}$ bought are assumed to be consumed. $\mathrm{P}$ traders gain utility from

${ }^{1}$ Assume that $U(a)$ is well behaved if it is defined, strictly monotonic, and twice continuously differentiable on the nonnegative orthant $a \geq 0$. Then, $\mathrm{U}(a)$ is additively separable if it can be written as $U(a)=U\left(a^{1}, \ldots . a^{T}\right)=\sum f^{t}\left(x^{t}\right), \quad T>2$ in an appropriate normalization. 
trading and speculation. Any units of $\mathrm{L}$ not used to produce goods are worthless. Similarly any unit of $\mathrm{X}, \mathrm{Y}$ and $\mathrm{Z}$ that is not sold is valueless to them. All market activities are denoted in an experimental currency "franc".

Table 1: Experimental Parameters

\begin{tabular}{lccc}
\hline Preferences: & Country 1 & Country 2 & Country 3 \\
\hline $\mathrm{U}(\mathrm{X}, \mathrm{Y}, \mathrm{Z})=600 \mathrm{X}-45 \mathrm{X}^{2}+720 \mathrm{Y}-45 \mathrm{Y}^{2}+840 \mathrm{Z}-45 \mathrm{Z}^{2}$ & & \\
Endowments of input factor (L): & 2 & 3 & 4 \\
Consumers & 1 & 1 & 1 \\
Producers & & & \\
Number: & 3 & 3 & 3 \\
Consumers & 3 & 3 & 3 \\
Producers & 9 & 12 & 15 \\
Total Endowment & $\mathrm{X}=4 \mathrm{~L}$ & $\mathrm{X}=\mathrm{L}$ & $\mathrm{X}=\mathrm{L}$ \\
Production & $\mathrm{Y}=\mathrm{L}$ & $\mathrm{Y}=3 \mathrm{~L}$ & $\mathrm{Y}=2 \mathrm{~L}$ \\
& $\mathrm{Z}=\mathrm{L}$ & $\mathrm{Z}=2 \mathrm{~L}$ & $\mathrm{Z}=3 \mathrm{~L}$ \\
\hline
\end{tabular}

The Tariff-Distorted Environment: When Countries 2 and 3 impose a tariff of 320 francs on imports of good X; countries 1 and 3 impose a tariff of 240 on imports of Y; countries 1 and 2 impose a tariff of 340 francs on imports of $Z$. Tariff revenue was not redistributed to but retained by the experimenter. As such, the tariff operated like a transport cost.

The Customs Union Environment: Here, countries 1 and 2 abolish tariffs on trade and impose a CET on imports of Z from country 3, which imposes a tariff on imports of X and Y. Countries 1 and 2 impose a tariff of 340 francs on the imports of Z; country 3 one of 240 on imports of $Y$ and a tariff of 320 francs on the imports of $\mathrm{X}$.

The upper part of Figure 1 shows the circular flow in country 2, the lower left and lower right circular flows of countries 1 and 3 respectively. There are 12 markets in operation in the experiment. Each variable has its own market: Outputs $\mathrm{X}_{\mathrm{i}}, \mathrm{Y}_{\mathrm{i}}$ and $\mathrm{Z}_{\mathrm{i}}$ produced in country $\mathrm{i}$ have their own markets $(\mathrm{i}=1$, 2 , 3). Labour, $L_{i}$, in each country has its own market. Trade occurs when goods are sold to agents in countries where production did not take place. The dotted arrows show the various tariffs imposed.

Procedures: Eight experiments with a subject pool of 18 (6 in each country) were conducted. ${ }^{2}$ Experiments 1- 4 relate to the TD and 5- 8 to the CU environment. Subjects had an hour practice session in the use of MUDA before the experiment (for which they were paid) and were not allowed to participate in more than one experiment. Each experiment was divided into 5 periods of 10 minutes. Once assembled subjects were randomly assigned as Type C or P agents and kept the same role. Instructions were given to both with information on: subject's type and number of goods in the computerized market; endowment and cash on hand; operation of the market system; the production schedule and redemption values; trading profits, earnings and market restrictions (which included information about taxes). Full details of these are given in Appendices 2 and 3. Basic information about MUDA included how to buy/ sell units, what numbers in the boxes meant and transformation functions. In the practice period accounting records were checked carefully for errors and subjects reminded of the production and consumption process. In later periods spot checks were undertaken to verify accounting information. Subjects were also asked to check changes in cash on hand, endowments and contract history. The redemption values and production schedule were the same for each period; subjects received new endowments and cash on hand at the beginning of each period.

\footnotetext{
${ }^{2}$ Subjects were undergraduates from the University of Nottingham. Most were non-economics students.
} 
Figure 1: The Market System

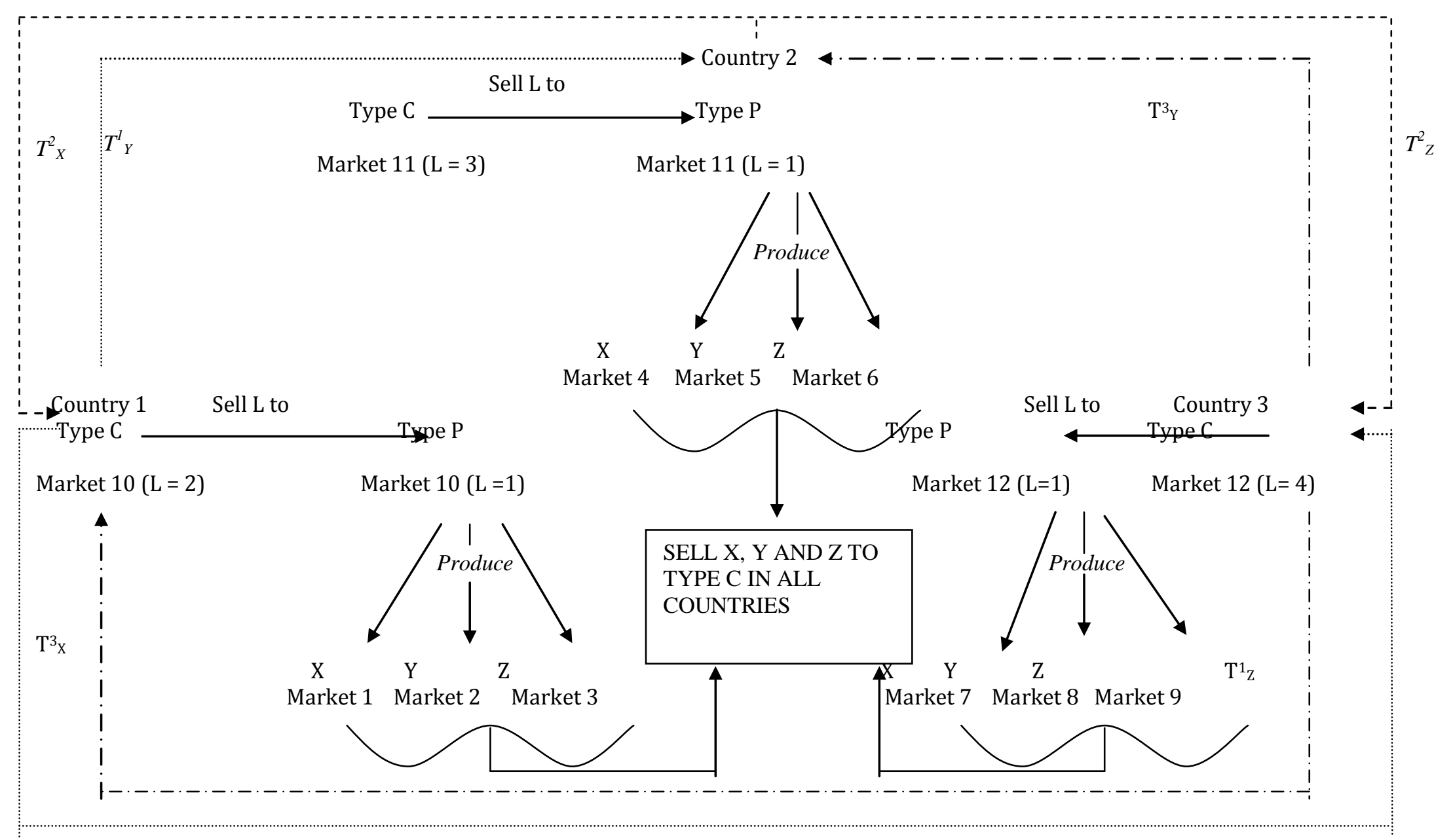




\section{Theoretical Predictions}

Predictions about two environments are made namely the tariff- distorted environment and customs union environment.

Tariff -Distorted Environment: The 3 x 3 CRM consists of 3 countries (i = 1, 2, 3), 3 output goods $(j=X$, $\mathrm{Y}, \mathrm{Z}$ ) and an input factor (L). The outputs can be produced using the same input, paralleling the CRM of trade theory. Countries differ in their level of endowment (L) which is supplied inelastically. Countries also differ in their production technologies. From Table 1, the constant labour costs of producing a unit of good $j$ in country $i$ are:

\begin{tabular}{lllll}
\hline & & \multicolumn{3}{c}{ Country } \\
\hline \multirow{4}{*}{ Good } & & 1 & 2 & 3 \\
& $\mathrm{X}$ & $1 / 4$ & 1 & 2 \\
& $\mathrm{Y}$ & 1 & $1 / 3$ & $1 / 2$ \\
& $\mathrm{Z}$ & 1 & $1 / 2$ & $1 / 3$ \\
\hline
\end{tabular}

Each country produces and exports the good in which it has comparative advantage and imports the other two. The production technologies satisfy Jones (1961) optimum efficient assignment of production when countries 1, 2 and 3 specialise in goods $\mathrm{X}, \mathrm{Y}$ and $\mathrm{Z}$ respectively. Countries have identical aggregate demand for all three goods.

When a tariff is in place, it takes the form of $\mathrm{T}$ on the goods in which country $\mathrm{i}$ has comparative advantage. Each country determines its own tariffs by maximising the tariff distorted utility function. Starting from free trade, the introduction of the tariff creates a price wedge and shifts consumption from the importing countries to the exporting country. The introduction of tariffs does not disturb production as supplies of goods are inelastic.

The theoretical predictions are derived in the following way. Total endowments give us production levels of $\mathrm{X}, \mathrm{Y}$ and $\mathrm{Z}$ in each country. Free trade aggregate demand in each and total aggregate demand are computed from the utility function, from which free trade prices are derived. The tariff causes a price wedge between the exporting and importing prices, giving the new tariff distorted demand in each; from which new quantity demanded is obtained. The next step involves substituting tariff distorted demand into the utility functions which are differentiated to derive import tariffs. Using these figures, prices of each good, net exports and terms of trade are derived ${ }^{3}$.

Table 2: Tariff-Distorted Predictions

\begin{tabular}{llll}
\hline Variables & Country 1 & Country 2 & Country 3 \\
\hline Production & & & \\
X & 36 & - & - \\
Y & - & 36 & - \\
Z & - & - & 45 \\
Export & & & \\
$X$ & 13.33 & - & - \\
Y & - & 16 & - \\
Z & - & - & 18.66 \\
Prices & & & \\
$X$ & 80 & - & - \\
Y & - & 240 & - \\
$Z$ & - & - & 220 \\
L & 320 & 720 & 660
\end{tabular}

\footnotetext{
${ }^{3}$ The computation and description of the tariff distorted are in a technical Appendix available from the authors.
} 


\section{Tariffs}

$\mathrm{T}_{\mathrm{X}}$

$\mathrm{T}_{\mathrm{Y}}$

$\mathrm{T}_{\mathrm{Z}}$

Terms of Trade
320

240

340

0.153
320

240

340 -

$0.487 \quad 0.495$

Customs Union Predictions: When the CU is in place, countries 1 and 2, eliminate tariffs on trade between them and impose a common external tariff on imports of $\mathrm{Z}$ from country 3 (ROW). Country 3 retaliates with its own tariffs on goods $\mathrm{X}$ and $\mathrm{Y}$. We abstract from the determination of the common external tariff (CET) by keeping tariffs at the same level as in the tariff distorted experiment ${ }^{4}$. As noted earlier, the effect of CU membership is ambiguous because ex ante we do not know the balance of trade diversion and trade creation. Venables (2003) argues the outcome 'depends on the comparative advantage of members relative to each other and relative to the rest of the world'. Specifically, the country with 'extreme comparative advantage' will generally be more vulnerable to trade diversion.

The removal of import tariffs within the union increases trade among members, causes a reallocation of consumption and improves the terms of trade. The assumption of perfectly inelastic supply of exports implies production will not change. However, a CU will change the pattern of trade which determines the source of trade diversion. The product of wage rates and unit labour coefficient gives the cost of producing each good. When goods face a tariff, that rate is set at T. Following Venables (2003), country 1 will now import any good from country 2 for which $P_{L 2} a_{L J}^{2}<P_{L 1} a_{L J}^{1}$ and $P_{L 2} a_{L J}^{2}<P_{j}^{M}$ where $a_{L J}^{2}$ denotes constant labour costs of producing a unit of $\mathrm{j}$ in country 2; $a_{L J}^{1}$ denotes constant labour costs of producing a unit of good $\mathrm{j}$ in country $1 ; P_{L 1}$ and $P_{L 2}$ denote prices of labour in countries 1 and 2 respectively and $P_{j}^{M}$ denotes the tariff distorted price of good $\mathrm{j}$. We observe trade diversion if this particular good is now being imported from the trading partner rather than the least-cost producer and the "....extreme comparative advantage country will have a higher proportion of goods changing source of supply and, most of these changes are trade diversion" (Venables, 2003, pp. 754).

Theoretical predictions are calculated as follows: aggregate demands of goods $\mathrm{X}$ and $\mathrm{Y}$ in the $\mathrm{CU}$ are derived from utility functions. Given production values and since quantities demanded of $X$ and $Y$ do not change in Country 3, we obtained CU consumption of $\mathrm{X}$ and $\mathrm{Y}$ as well as price from CU demand curves. Using new individual demand curves in each and tariff levels, individual quantity demanded are obtained. Country 1 (the extreme comparative advantage member) changes its source of supply of $Z$ from 3 to 2 trade diversion. Equilibrium trade diversion is calculated as: $\left(\mathrm{P}_{\mathrm{L} 2} \mathrm{a}^{2} \mathrm{LZ}-\mathrm{P}_{\mathrm{Z}}{ }^{*}\right) \mathrm{Z}_{\mathrm{m}}$ where $\mathrm{P}_{\mathrm{L} 2}$ denotes price of labour in country $2, \mathrm{a}^{2} \mathrm{LZ}$ labour requirement of $\mathrm{Z}$ in country $2, \mathrm{P}_{\mathrm{Z}}{ }^{*}$ outside world price of $\mathrm{Z}$ and $\mathrm{Z}_{\mathrm{m}}$ denotes imports of $\mathrm{Z}$ by country 1 . The theoretical derivations are computed in a similar way to the tariff distorted environment.

\footnotetext{
${ }^{4}$ This is consistent with the GATT-constrained CU. A GATT-constrained $C U$ is a union that abides by Article XXIV of the GATT. Article XXIV of GATT (WTO) requires members of customs unions not to raise their external tariffs beyond pre-union.
} 
Table 3: Customs Union Predictions

\begin{tabular}{|c|c|c|c|}
\hline \multirow{2}{*}{ Variables } & \multicolumn{2}{|c|}{ Customs Union } & \multirow{2}{*}{$\frac{\text { Row }}{\text { (Country 3) }}$} \\
\hline & Country 1 & Country 2 & \\
\hline \multicolumn{4}{|l|}{ Production } \\
\hline $\mathrm{X}$ & 36 & - & - \\
\hline Y & - & 36 & - \\
\hline $\mathrm{Z}$ & - & - & 45 \\
\hline \multicolumn{4}{|l|}{ Export } \\
\hline $\mathrm{X}$ & 18.66 & - & - \\
\hline Y & - & 20 & - \\
\hline $\mathrm{Z}$ & - & - & 18.66 \\
\hline \multicolumn{4}{|l|}{ Prices } \\
\hline $\mathrm{X}$ & 160 & - & - \\
\hline Y & - & 300 & - \\
\hline $\mathrm{Z}$ & - & - & 220 \\
\hline $\mathrm{L}$ & 640 & 900 & 660 \\
\hline \multicolumn{4}{|l|}{ Tariffs } \\
\hline TCET & 340 & 340 & - \\
\hline $\mathrm{T}_{\mathrm{Y}}$ & - & - & 320 \\
\hline $\mathrm{T}_{\mathrm{z}}$ & - & - & 240 \\
\hline Terms of Trade & 0.182 & 0.892 & 0.495 \\
\hline Trade Diversion & 2145.9 & - & - \\
\hline
\end{tabular}

After formation of the $\mathrm{CU}$; there are increases in net exports of $\mathrm{X}$ from country 1 to 2 . Similarly net exports of Y from 2 to 1 rise. Lastly, net exports of goods X and Y vis-à-vis country 3 decreases; consumption of $X$ in country 1 (2) decreases (increases) whereas consumption of $Y$ decreases (increases) in country 2 (1); there is a terms of trade; equilibrium trade diversion in our model is 2145.9 francs per period and 42918 francs for the whole experiment. Based on these predictions, the following hypotheses are tested:

1: A CU increases trade flows within the union and decreases trade flows outside it.

2: A CU decreases consumption of good $\mathrm{X}(\mathrm{Y})$ in country $1(2)$..

3: Following formation of the $\mathrm{CU}$, consumption of good $\mathrm{X}$ and $\mathrm{Y}$ do not change.

4: A CU increases the terms of trade of members.

5: The extreme comparative advantage country loses from trade diversion.

\section{Methodology}

We are interested in convergence in the variables for both models. To account for within and across period changes, we apply a modified version of the Ashenfelter-El-Gamal model (first used in Riedl and Winden (2005)). 


$$
\begin{aligned}
A_{i t}= & B_{11} D_{1 B}\left(\frac{1}{t}\right)+\ldots \ldots+B_{1 i} D_{i B}\left(\frac{1}{t}\right)+\ldots \ldots B_{1 n} D_{n B}\left(\frac{1}{t}\right)+B_{2} D_{B}\left(\frac{t-1}{t}\right) \\
& +C_{11} D_{1 C}\left(\frac{1}{t}\right)+\ldots \ldots+C_{1 i} D_{i C}\left(\frac{1}{t}\right)+\ldots \ldots C_{1 n} D_{n C}\left(\frac{1}{t}\right)+C_{2} D_{C}\left(\frac{t-1}{t}\right)+u_{i t}
\end{aligned}
$$

$A_{i t}$ is the variable of interest in period $t$ for experiment $i, i=1 \ldots . n$. $D_{i \text { в }}$ are dummy variables that take a value of 1 for experiment $i$ of the TD system, and 0 otherwise. $D_{i c}$ is a dummy variable representing experiment $\mathrm{i}$ of the $\mathrm{CU}$ system. $\mathrm{D}_{\mathrm{B}}$ is equal to 1 when the TD system is effective whereas $\mathrm{D}_{\mathrm{C}}=1$ when the $\mathrm{CU}$ is in effect (and $u$ is random error). Assume we are interested in the tariff distorted production of $Y$; when $t=1$, production of $Y$ in experiment $i$ equals $B_{1 i}$, the coefficient of which can be interpreted as initial production of Y. However, its impact reduces over time, as $\left(\frac{1}{t}\right)$ tends to zero when $\mathrm{t}$ increases. Compared to $\mathrm{B}_{1}$, when $\mathrm{t}$ increases the impact of $\mathrm{B}_{2}$ increases as $\left(\frac{t-1}{t}\right)$ gets larger. Thus, the coefficient $\mathrm{B}_{2}$ can be interpreted as the common asymptote of production of $\mathrm{Y}$. Similarly, $\mathrm{C}_{1 \mathrm{i}}$ denotes session specific starting value and $\mathrm{C}_{2}$ the asymptotic value of production of $\mathrm{Y}$, for the $\mathrm{CU}$ system.

To observe strong convergence of $A_{i t}$, it suffices to test whether the estimates of $B_{2} / C_{2}$ are significantly different from the predictions of the model. If not, the variable is strongly converging to the predicted values. However, as pointed by Noussair et al (1995), we can also observe weak or partial convergence. The former occurs if $B_{2}$ 's / $C_{2}$ 's are quantitatively closer to the predictions than $B_{1 \mathrm{i}} / \mathrm{B}_{1 \mathrm{i}}$ are. Since we are interested in the difference between the asymptotic value of the TD and CU systems, we used the Wald test to test whether the difference in $\mathrm{B}_{2}$ and $\mathrm{C}_{2}$ is equal to zero.

\section{Results and Discussion}

At the end of each experiment, a series of input and output prices are generated. These include ask, bid and contract prices. Figures 2- 5 present the contract output and input prices for Experiments 3 (tariff distorted) and 6 (CU). The $\mathrm{x}$-axis denotes time measured in seconds. which gives the exact second of accepted bids or asks. The y-axis denotes prices (francs). The vertical lines parallel to the y-axis show the beginning and end of each period and the gap the time interval between periods. Nothing happens during this interval and subjects completed their record sheets. Although all observed contract prices do not automatically cluster towards the competitive equilibrium, there is some convergence in some markets.

\section{Figure 2: Output Price Time Series-TD Environment (Experiment 3)}

\section{Price- Market $X$}

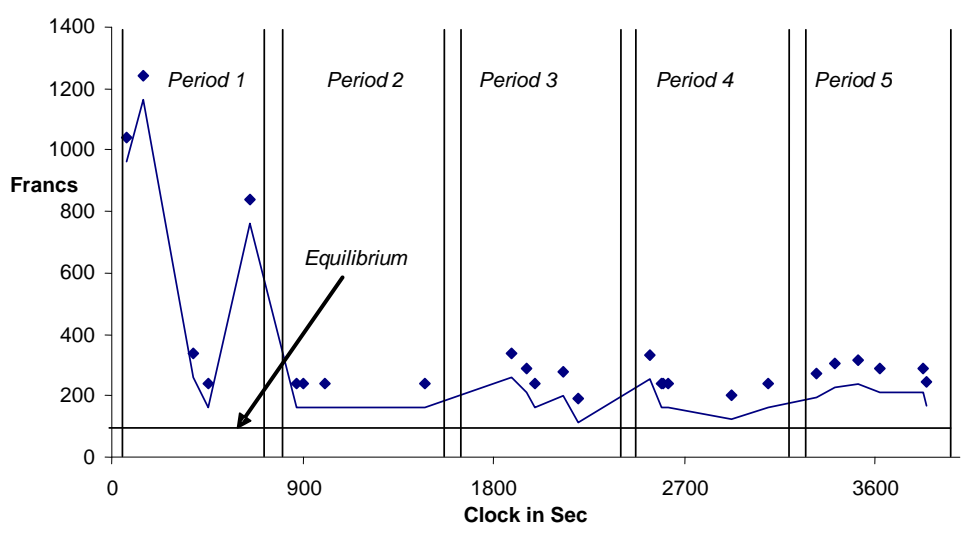




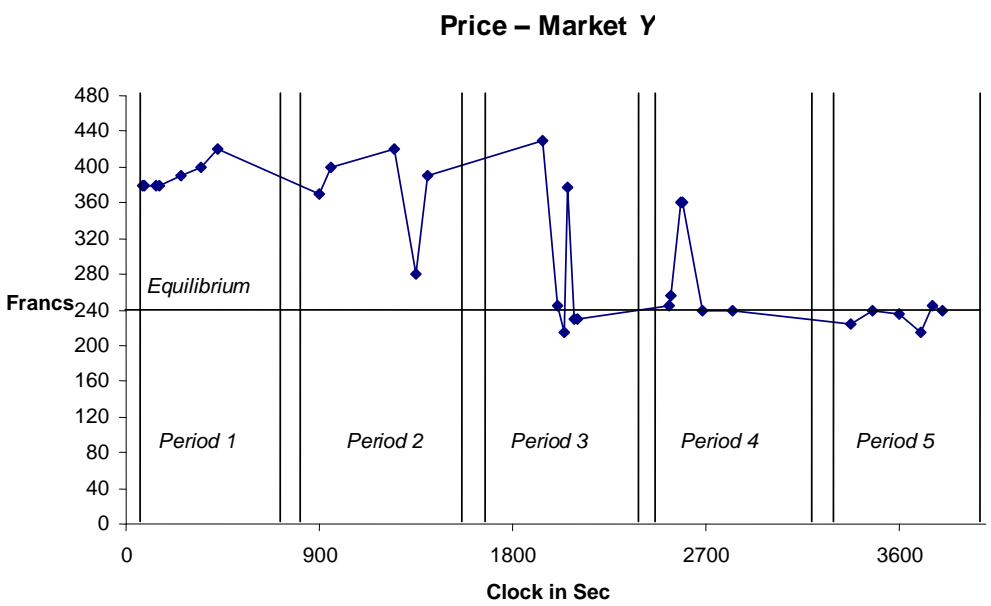

Price- Market $Z$

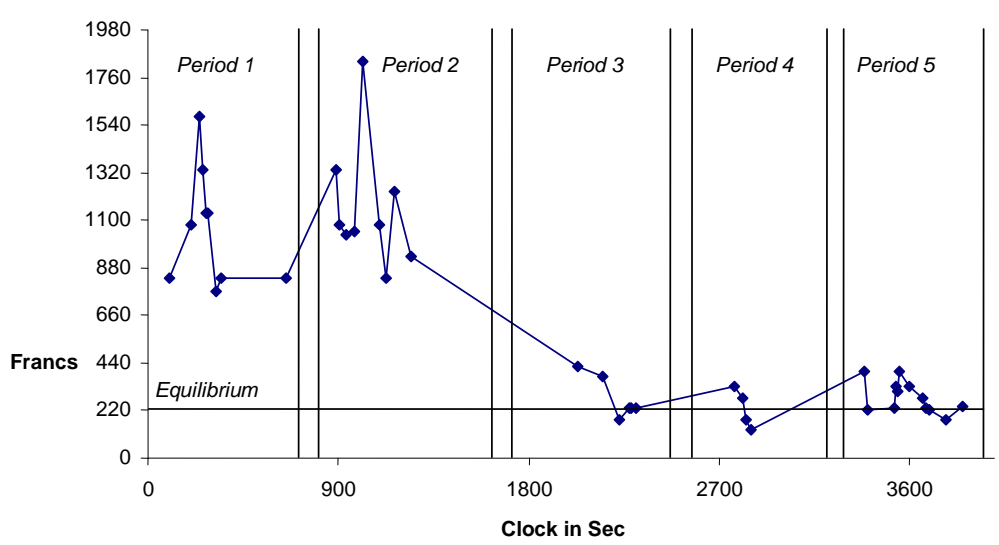

Figure 3: Input Price Time Series- TD Environment (Experiment 3)

Price of L- Country 1

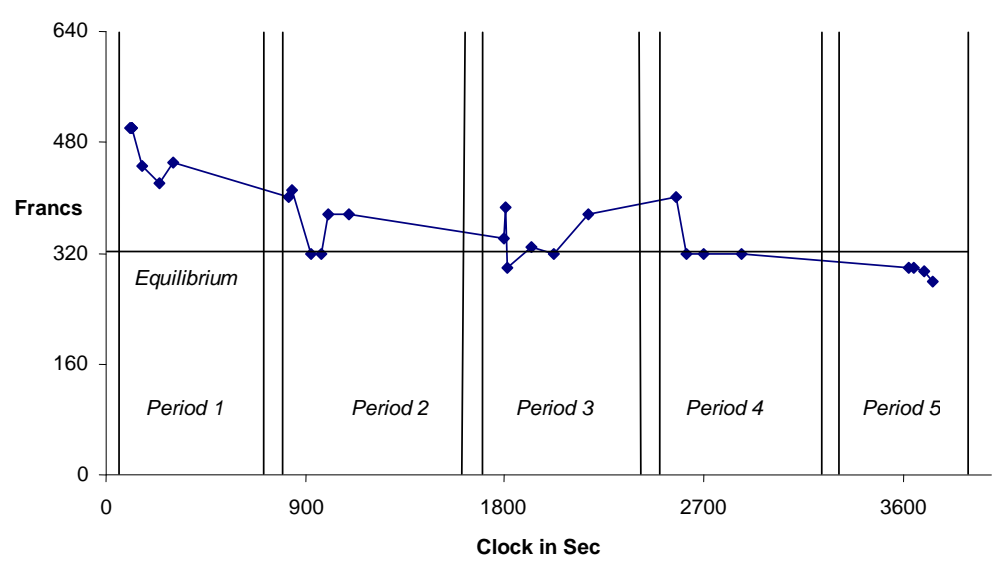


Price of $L$ - Country 2

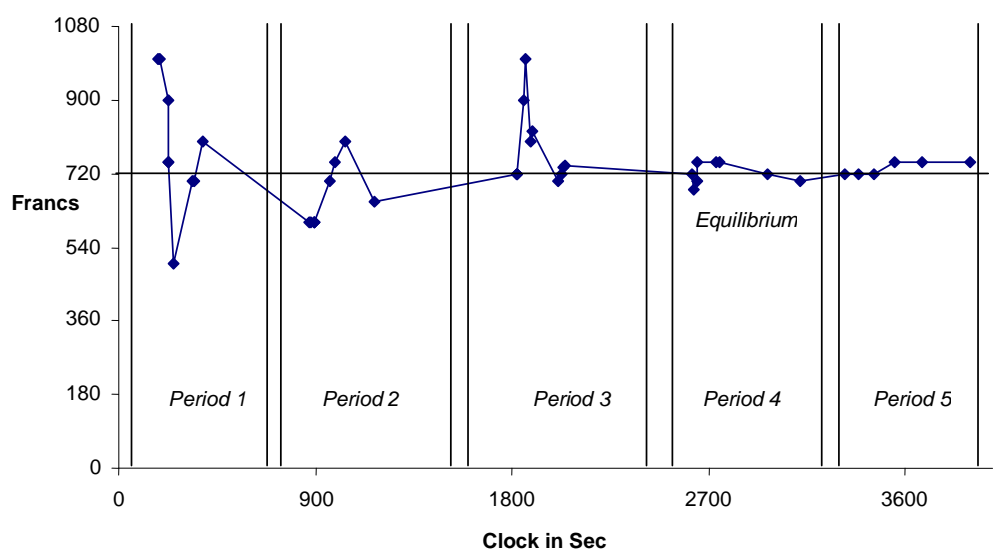

Price of $L$ - Country 3

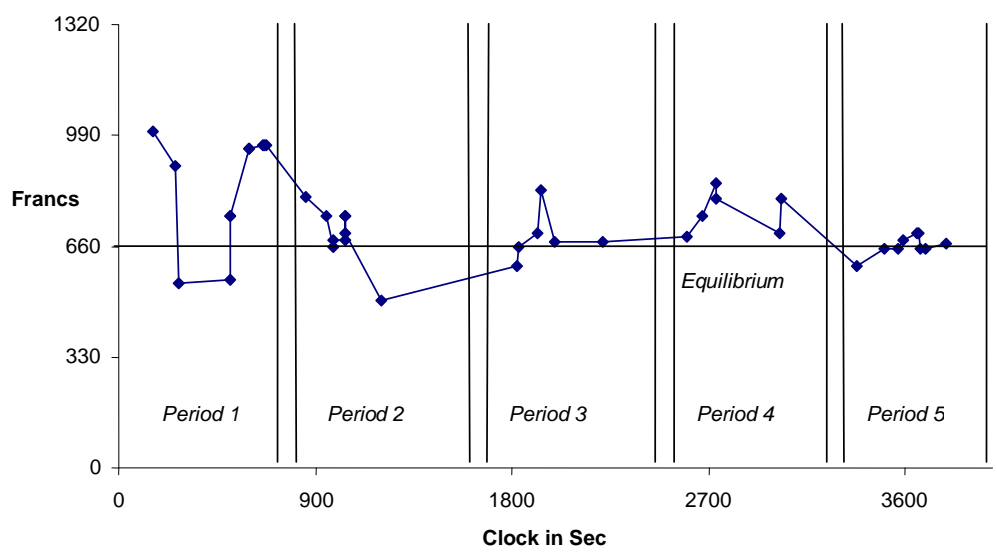

Figure 4: Output Price Time Series- CU Environment (Experiment 6)

Price - Market X

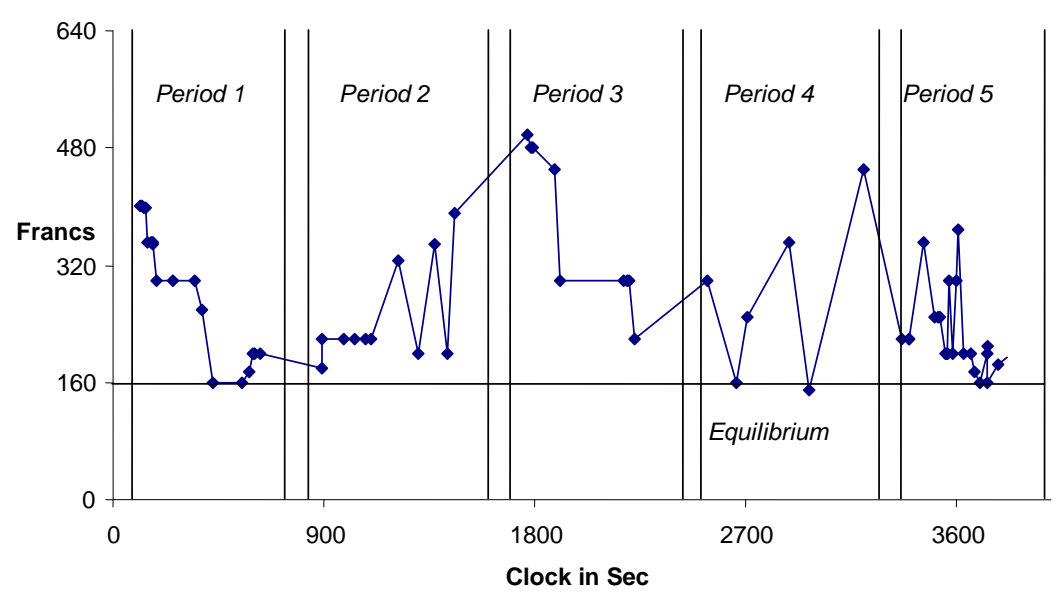


Price - Market $Y$

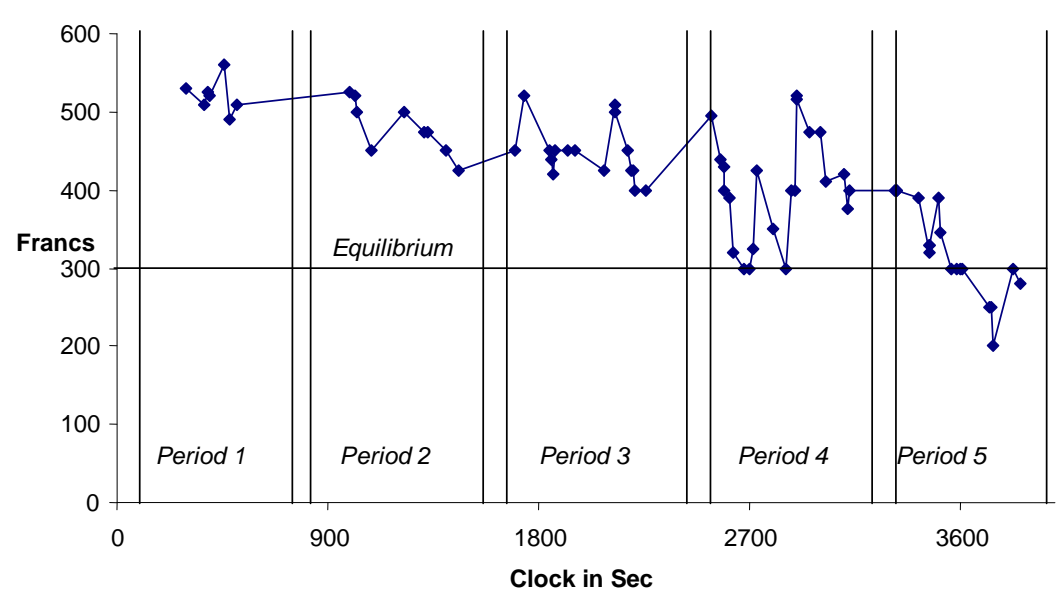

Price - Market Z

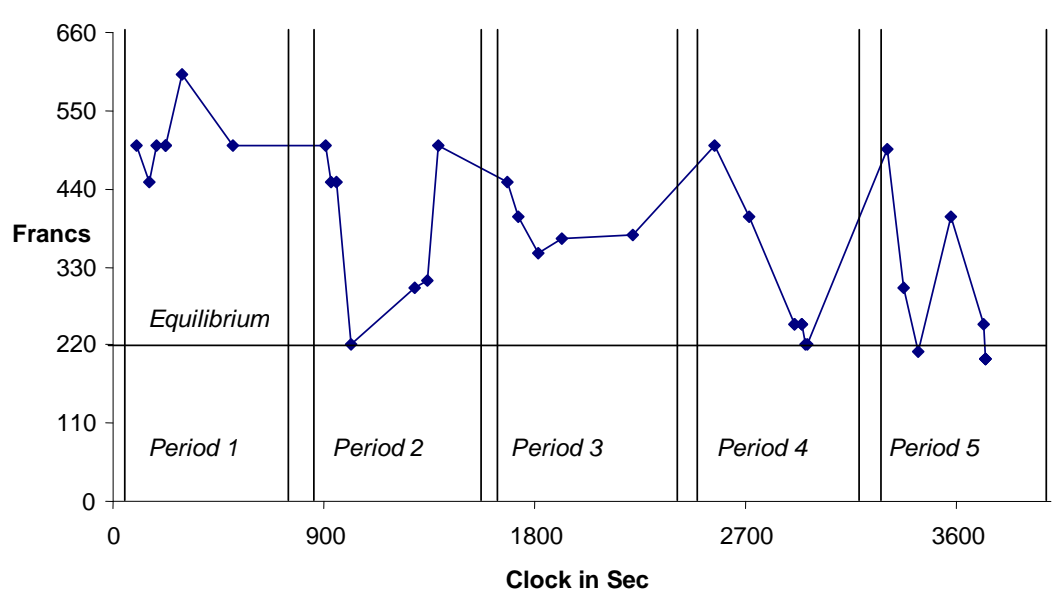

Figure 5: Input Price Time Series- CU Environment (Experiment 6)

Price of L- Country 1

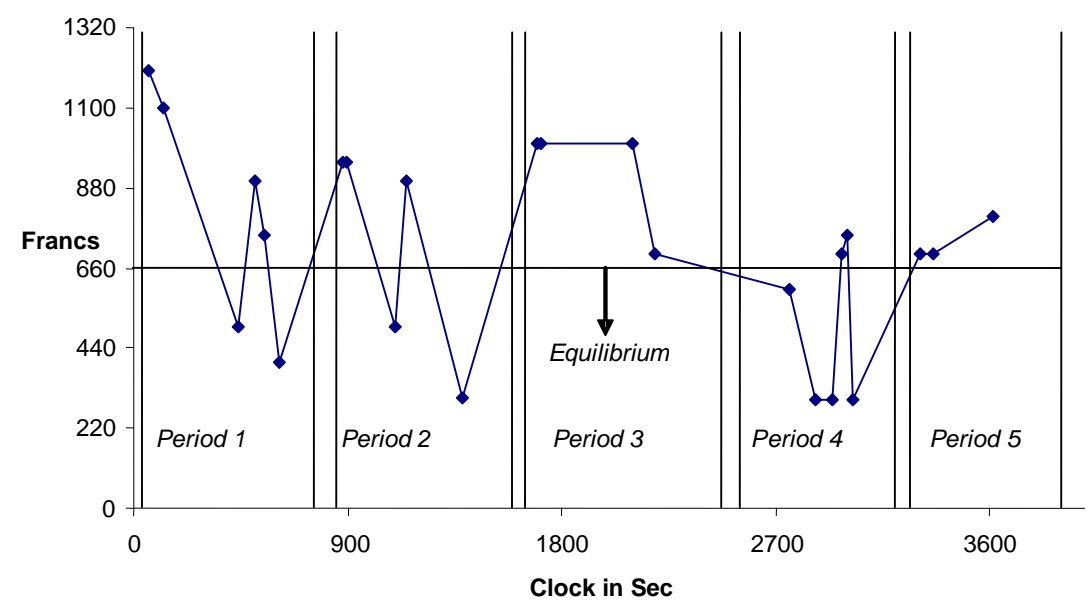


Price in L- Country 2

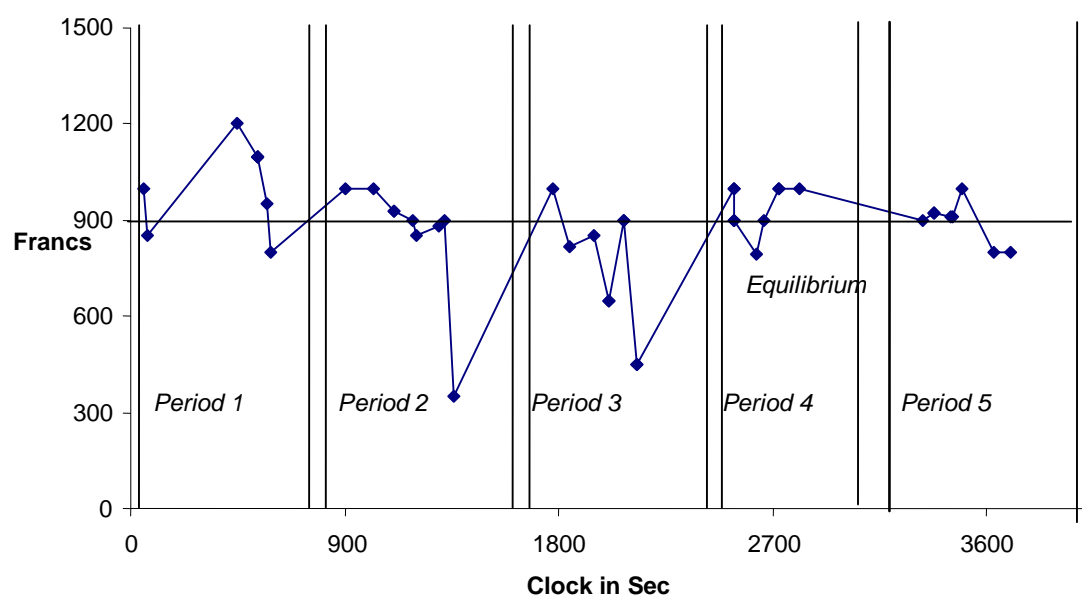

Price in L- Country 3

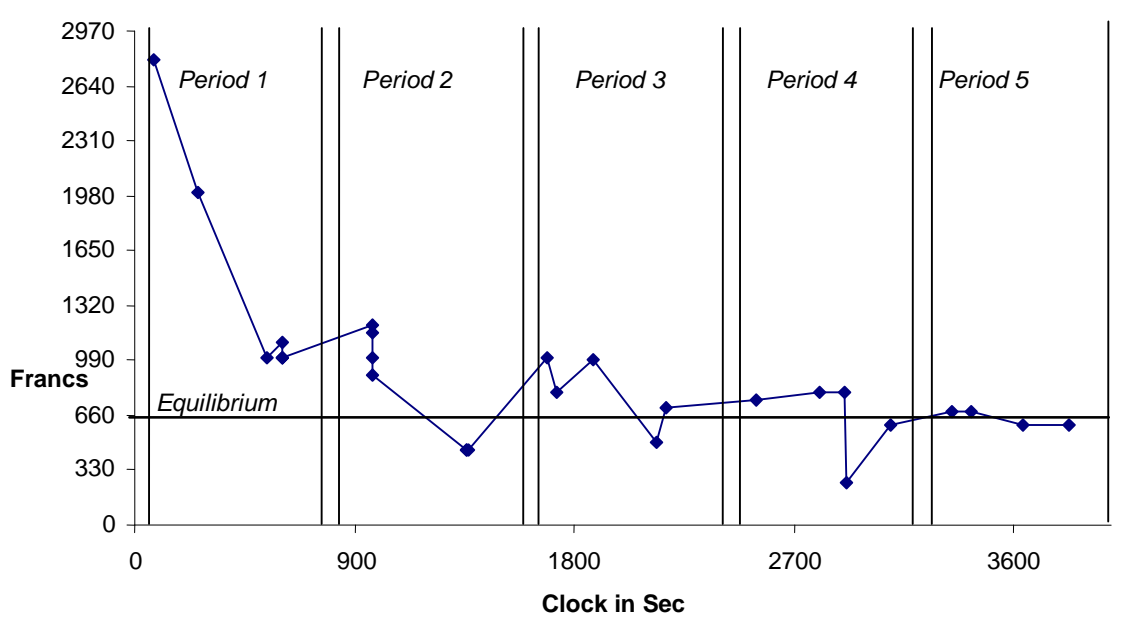

Customs Unions and Tariff- Distorted Environment: Table 4 compares production and trade in the two environments. Bold figures represent data for the good in which each country is specialised. Following creation of the CU, production of $\mathrm{X}$ in country 1 increases by $2.6 \%$ and of $\mathrm{Y}$ by $6.7 \%$, whilst production of $\mathrm{Z}$ decreases by $22.8 \%$. Table 4 also reveals that intra- union export of $\mathrm{X}$ and $\mathrm{Y}$ rise by $123.2 \%$ and $336.7 \%$ respectively with a decline in trade to and from country 3 . Exports of $Z$ to 1 and 2 decline by $18.2 \%$ and $307.2 \%$ respectively. Similarly, exports of $X$ and $Y$ from the CU vis-à-vis country 3 decline by $70.9 \%$ and $28.6 \%$ respectively.

Table 4: TD Environment v/s CU Environment (All Experimental Sessions)

\begin{tabular}{|c|c|c|c|c|c|c|c|}
\hline \multirow{5}{*}{ Country 1} & \multirow{2}{*}{ Good } & \multicolumn{2}{|c|}{ Production } & \multicolumn{2}{|c|}{ Net Export to Country 2} & \multicolumn{2}{|c|}{ Net Export to Country 3} \\
\hline & & TD & $\mathrm{CU}$ & TD & $\mathrm{CU}$ & $\mathrm{TD}$ & $\mathrm{CU}$ \\
\hline & $\mathrm{X}$ & 384 & 394 & 82 & 183 & 55 & 16 \\
\hline & Y & 29 & 30 & 5 & 12 & 13 & 10 \\
\hline & $\mathrm{Z}$ & 33 & 32 & 6 & 16 & 16 & 8 \\
\hline \multirow{5}{*}{ Country 2} & \multirow{2}{*}{ Good } & \multicolumn{2}{|c|}{ Production } & \multicolumn{2}{|c|}{ Net Export to Country 1} & \multicolumn{2}{|c|}{ Net Export to Country 3} \\
\hline & & TD & $\mathrm{CU}$ & TD & $\mathrm{CU}$ & TD & $\mathrm{CU}$ \\
\hline & $\mathrm{X}$ & 28 & 23 & 4 & 2 & 11 & 6 \\
\hline & Y & 315 & 336 & 30 & 131 & 35 & 25 \\
\hline & $\mathrm{Z}$ & 216 & 220 & 30 & 94 & 90 & 8 \\
\hline
\end{tabular}




\begin{tabular}{cccccccc} 
& \multirow{2}{*}{ Good } & Production & \multicolumn{3}{c}{ Net Export to Country 1 } & \multicolumn{2}{c}{ Net Export to Country 2 } \\
\cline { 2 - 8 } Country 3 & TD & CU & TD & CU & TD & CU \\
\cline { 2 - 8 } & X & 56 & 35 & 8 & 9 & 20 & 8 \\
& Y & 212 & 158 & 79 & 29 & 37 & 15 \\
& Z & 369 & 285 & 44 & 36 & 57 & 14 \\
\hline
\end{tabular}

Table 5 reports results for the convergence regressions of production in the three countries. Comparison of $\mathrm{B}_{2}$ and $\mathrm{C}_{2}$ indicates whether there are changes. The p-value tests the hypothesis that the asymptotic values of $\mathrm{B}_{2}$ and $\mathrm{C}_{2}$ are equal (two-sided Wald Test). If it is greater than 0.05 , there is no evidence to reject the null hypothesis (production of $\mathrm{X}, \mathrm{Y}$ and $\mathrm{Z}$ does not change with formation of the $\mathrm{CU}$ ). Standard errors are given in italics (corrected for both session specific heteroskedasticity and serial correlation). As can be seen, there is no evidence of any changes in production in any countries. We fail to reject the null hypothesis that production of $\mathrm{X}, \mathrm{Y}$ and $\mathrm{Z}$ does not change following creation of the $\mathrm{CU}$.

Result 1: Customs Union formation increases trade flows within the union. Trade flows outside the CU tend not to change: Table 6 reports results for the convergence regressions, for net exports. Our theoretical predictions are that country 1's net exports of X to country 2 increase following formation of the CU. Similarly, there is an increase in net exports of $\mathrm{Y}$ to country 1 . However, net exports to the nonmember country does not change, nor do net exports of $\mathrm{Z}$. We compared $\mathrm{B}_{2}$ and $\mathrm{C}_{2}$ to check for changes. Compared to the tariff distorted system, we observe an increase in net exports of X to country 2 (from 4.92 to 8.23 units). Similarly, net exports of $Y$ to country 1 show a statistically significant better outcome under the CU (9.21 units) than the tariff distorted system (1.56 units). Thus, there is an increase in intraunion net exports of goods $\mathrm{X}$ and $\mathrm{Y}$ following dismantling of tariffs between countries 1 and 2 .

The $\mathrm{p}$-value indicates no change in net exports of goods $\mathrm{X}$ and $\mathrm{Y}$ to country 3 . These are 1.58 units for the CU compared to 2.94 units and 1.88 units compared to 1.94 units for $\mathrm{X}$ and $\mathrm{Y}$ respectively. Also net exports of $\mathrm{Z}$ tend not to change. The null hypothesis that there is no change in net exports of $\mathrm{Z}$ after creation of the $\mathrm{CU}$ is rejected. Thus, we conclude that net exports of good $\mathrm{X}$ and $\mathrm{Y}$ from the $\mathrm{CU}$ are the same as under the tariff distorted environment and net exports of good $\mathrm{Z}$ from ROW to CU remain constant when the $\mathrm{CU}$ is established. This finding is consistent with the general perception that creation of trading blocks always increase trade withinh the block.

Result 2: Customs Union formation increases consumption of good $X(Y)$ in country1/(2): Following establishment of the $\mathrm{CU}$, there is a consumption gain in $\mathrm{X}$ of $53.9 \%$ in country 2 and of $\mathrm{Y}$ by $73.0 \%$ in country 1 . Comparing $B_{2}$ to $C_{2}$ in country 1 in Table 7 reveals a decrease in consumption of $X$ (at the $10 \%$ level of significance); an increase in consumption of $Y$ (from 4.73 units to 11.12 units); and an increase in consumption of $\mathrm{Z}$. In country 2 we observe: an increase in consumption of X (from 6.38 units to 9.35 units); although in absolute terms $C_{2}$ is less than $B_{2}$, we fail to reject the null that consumption levels of $Y$ and $\mathrm{Z}$ do not change with the CU. In country 3 , all our theoretical predictions are satisfied as consumption of $\mathrm{X}, \mathrm{Y}$ and $\mathrm{Z}$ do not change after the $\mathrm{CU}$ is formed. We made nine predictions about consumption levels and seven are observed. Following establishment of the $\mathrm{CU}$, we observed an increase in consumption of $\mathrm{X}$ in country 2 and an increase in consumption of $Y$ in country 1.

Result 3: CU formation improves the terms of trade of member countries relative to non-member countries: We compute a weighted average terms of trade for the three countries. Our prediction is an improved terms of trade for members. Table 8 reports regression results. $B_{2}$ is 40.36 and $C_{2}$ is 73.21 for country 1 and $B_{2}$ is 41.01 and $C_{2}$ is 128.94 for country 2 . There is a general deterioration in the terms of trade for country $3 . B_{2}$ is 53.61 and $C_{2}$ is 24.78 for country 3 . Hence, our data supports toward improved terms of trade for members and a deterioration for non-members.

Result 4: The extreme comparative advantage country loses due to diversion: Equilibrium trade diversion is calculated as: $\left(\mathrm{P}_{\mathrm{L} 2} \mathrm{a}^{2}{ }_{\mathrm{LZ}}-\mathrm{P}_{\mathrm{Z}}{ }^{*}\right) \mathrm{Z}_{\mathrm{m}}$ where $\mathrm{P}_{\mathrm{L} 2}$ denotes price of labour in country $2, \mathrm{a}^{2}{ }_{\mathrm{LZ}}$ denotes labour requirement of $\mathrm{Z}$ in country $2, \mathrm{P}_{\mathrm{Z}}{ }^{*}$ denotes outside world price of $\mathrm{Z}$ and $\mathrm{Z}_{\mathrm{m}}$ denotes import of $\mathrm{Z}$ by country 1. Equilibrium trade diversion in our model is 2145.9 francs per period and 42918 francs for the whole experiment. Total trade diverted over the course of all experiments is 29420 francs compared to the benchmark of 42918 francs, i.e. $68.5 \%$. The pooled trade diversion observed in each period is given in Figure 6. 
Table 5: Convergence Regressions for Production: TD environment vs. CU environment

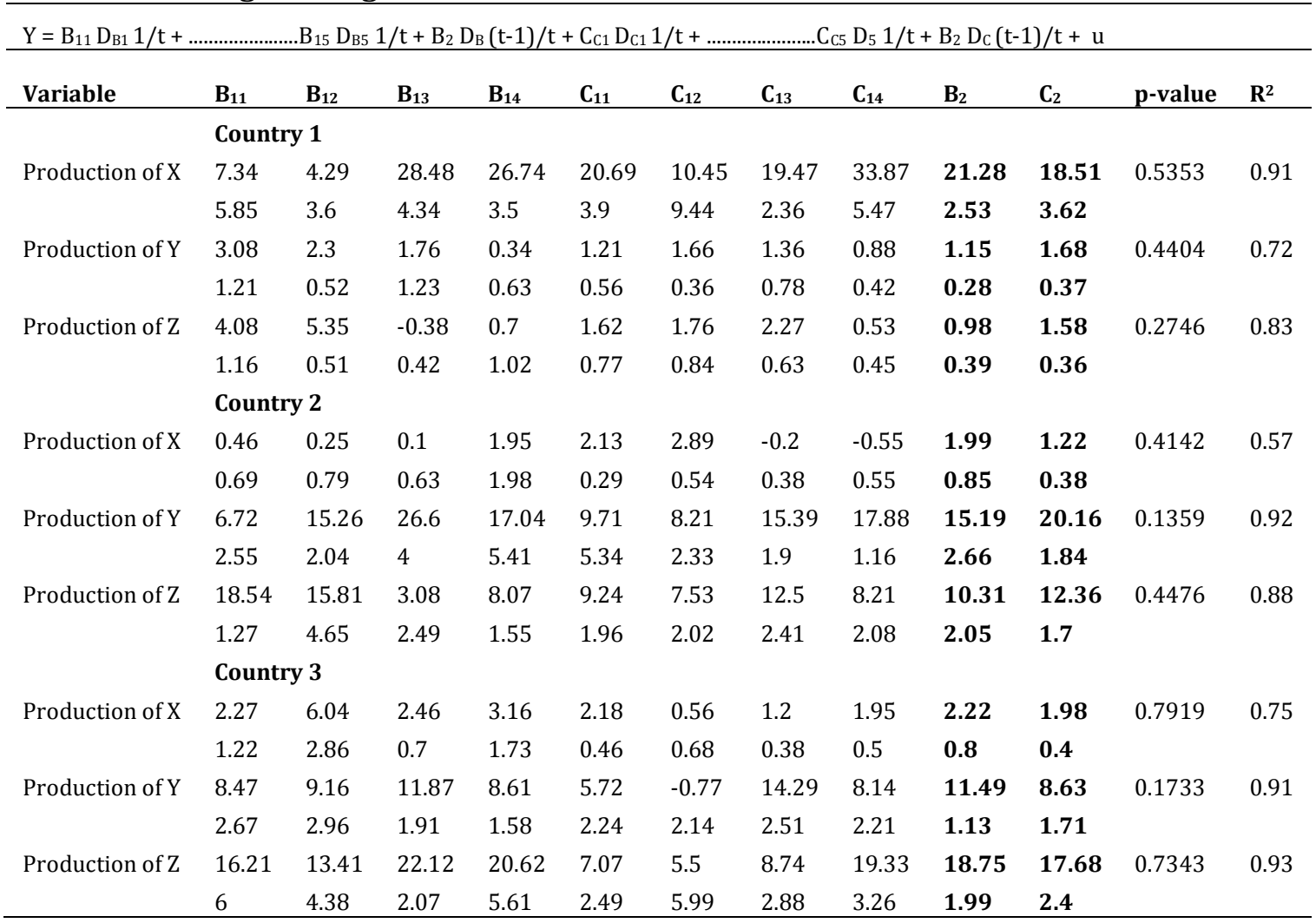

Table 6: Convergence Regressions for Net Exports: TD environment vs. CU environment

\begin{tabular}{|c|c|c|c|c|c|c|c|c|c|c|c|c|}
\hline Variable & $\mathbf{B}_{11}$ & $\mathbf{B}_{12}$ & $\mathbf{B}_{13}$ & $\mathbf{B}_{14}$ & $\mathrm{C}_{11}$ & $\mathrm{C}_{12}$ & $\mathrm{C}_{13}$ & $\mathrm{C}_{14}$ & $\mathbf{B}_{2}$ & $\mathrm{C}_{2}$ & p-value & $\mathbf{R}^{2}$ \\
\hline & \multicolumn{12}{|c|}{ Country 1} \\
\hline \multirow[t]{2}{*}{ Net Export X to Country 2} & 4.89 & 2.1 & 4.48 & 1.04 & 8.91 & 7.29 & 8.67 & 16.05 & 4.92 & 8.23 & 0.050 & 0.86 \\
\hline & 1.54 & 1.2 & 0.87 & 1.23 & 1.52 & 3.08 & 1.24 & 1.23 & 0.97 & 1.34 & & \\
\hline \multirow[t]{3}{*}{ Net Export X to Country 3} & 1.42 & 0.79 & 4.58 & 3.26 & -0.66 & -0.54 & 0.55 & 0.1 & 2.94 & 1.58 & 0.2267 & 0.65 \\
\hline & 2.43 & 0.54 & 1.67 & 1.26 & 0.711 & 0.66 & 1.05 & 0.69 & 0.86 & 0.68 & & \\
\hline & \multicolumn{12}{|c|}{ Country 2} \\
\hline \multirow[t]{2}{*}{ Net Export Y to Country 1} & 0.65 & 4 & 0.06 & 1.1 & 2.51 & 2.1 & 3.67 & 5.24 & 1.56 & 9.21 & 0.000 & 0.85 \\
\hline & 0.46 & 0.39 & 0.99 & 1.04 & 1.97 & 1.42 & 1.61 & 1.5 & 0.37 & 1.45 & & \\
\hline \multirow[t]{3}{*}{ Net Export Y to Country 3} & 0.82 & 3.12 & 0.52 & 1.72 & 0.11 & 0.04 & 1.53 & 0.31 & 1.92 & 1.88 & 0.9735 & 0.54 \\
\hline & 1.15 & 1.13 & 0.49 & 0.7 & 1.02 & 1.07 & 1.87 & 0.91 & 0.42 & 0.94 & & \\
\hline & \multicolumn{12}{|c|}{ Country 3} \\
\hline \multirow[t]{2}{*}{ Net Export Z to Country 1} & -0.7 & 1.8 & 2.28 & 1.98 & -0.29 & 1.06 & 3.56 & 2.16 & 2.92 & 1.94 & 0.2711 & 0.75 \\
\hline & 0.75 & 1.25 & 1.24 & 1.09 & 0.52 & 1.07 & 0.65 & 1.08 & 0.7 & 0.52 & & \\
\hline \multirow[t]{2}{*}{ Net Export Z to Country 2} & 1.91 & -0.53 & 3.57 & 2.02 & 1.02 & -0.48 & -0.07 & 0.43 & 2.78 & 1.09 & 0.115 & 0.72 \\
\hline & 1.04 & 0.69 & 0.61 & 1.25 & 1 & 0.56 & 0.44 & 0.86 & 0.84 & 0.62 & & \\
\hline
\end{tabular}


Table 7: Convergence Regressions for Consumption: TD environment vs. CU environment

\begin{tabular}{|c|c|c|c|c|c|c|c|c|c|c|c|c|}
\hline \multicolumn{13}{|c|}{$\mathrm{A}_{\mathrm{it}}=\mathrm{B}_{11} \mathrm{D}_{\mathrm{B} 1} 1 / \mathrm{t}+\ldots \ldots \ldots \ldots \ldots \ldots \ldots \ldots \ldots \mathrm{B}_{15} \mathrm{D}_{\mathrm{B} 5} 1 / \mathrm{t}+\mathrm{B}_{2} \mathrm{D}_{\mathrm{B}}(\mathrm{t}-1) / \mathrm{t}+\mathrm{C}_{\mathrm{C} 1} \mathrm{D}_{\mathrm{C} 1} 1 / \mathrm{t}+\ldots \ldots \ldots \ldots \ldots \ldots \ldots \mathrm{C}_{\mathrm{C} 5} \mathrm{D}_{5} 1 / \mathrm{t}+\mathrm{B}_{2} \mathrm{D}_{\mathrm{C}}(\mathrm{t}-1) / \mathrm{t}+\mathrm{u}$} \\
\hline Variable & $B_{11}$ & $\mathbf{B}_{12}$ & $\mathbf{B}_{13}$ & $B_{14}$ & $\mathrm{C}_{11}$ & $\mathrm{C}_{12}$ & $\mathrm{C}_{13}$ & $\mathrm{C}_{14}$ & $\mathbf{B}_{2}$ & $\mathrm{C}_{2}$ & p-value & $\mathbf{R}^{2}$ \\
\hline & \multicolumn{12}{|c|}{ Country 1} \\
\hline \multirow[t]{2}{*}{ Consumption of $\mathrm{X}$} & 3.79 & 2.76 & 11.79 & 14.23 & 12.07 & 1.06 & 6.65 & 14.82 & 11.56 & 7.45 & 0.091 & 0.89 \\
\hline & 1.67 & 1.71 & 2.02 & 1.23 & 2.42 & 3.76 & 1.7 & 2.67 & 1.68 & 1.73 & & \\
\hline \multirow[t]{2}{*}{ Consumption of Y } & 0.36 & 5.67 & 2.22 & 2.95 & 2 & 2.44 & 7.37 & 7.93 & 4.73 & 11.12 & 0.000 & 0.91 \\
\hline & 0.72 & 1.47 & 0.51 & 1.91 & 2.16 & 1.22 & 1.52 & 0.75 & 0.69 & 1.28 & & \\
\hline \multirow[t]{3}{*}{ Consumption of $\mathrm{Z}$} & 5.61 & 2.29 & 1.94 & 2.89 & 3.72 & 4.33 & 8.69 & 4.33 & 5.05 & 8.08 & 0.040 & 0.89 \\
\hline & 1.3 & 1.08 & 1.25 & 1.22 & 1.06 & 0.911 & 1.12 & 1.22 & 1.06 & 0.93 & & \\
\hline & \multicolumn{12}{|c|}{ Country 2} \\
\hline \multirow[t]{2}{*}{ Consumption of $\mathrm{X}$} & 5.7 & 2.7 & 4.45 & 3.59 & 8.63 & 7.55 & 9.14 & 15.56 & 6.38 & 9.35 & 0.050 & 0.88 \\
\hline & 1.64 & 0.42 & 0.87 & 1.59 & 1.71 & 3.01 & 1.33 & 1.38 & 0.91 & 1.32 & & \\
\hline \multirow[t]{2}{*}{ Consumption of Y } & 3.84 & 2.37 & 21.33 & 14 & 5.64 & 2.16 & 5.23 & 7.81 & 11.51 & 10.24 & 0.600 & 0.87 \\
\hline & 3.05 & 2.91 & 5.27 & 6.1 & 2.26 & 1.35 & 1.07 & 1.22 & 2.13 & 1.05 & & \\
\hline \multirow[t]{3}{*}{ Consumption of $\mathrm{Z}$} & 10.79 & -0.83 & 3.78 & 6.31 & 6.38 & 1.69 & 6.74 & 3.93 & 8.85 & 8.02 & 0.693 & 0.85 \\
\hline & 2.36 & 1.65 & 1.68 & 1.93 & 1.69 & 0.96 & 1.9 & 0.87 & 1.69 & 1.21 & & \\
\hline & \multicolumn{12}{|c|}{ Country 3} \\
\hline \multirow[t]{2}{*}{ Consumption of $\mathrm{X}$} & 4.18 & 0.77 & 5.13 & 5.48 & 2.04 & -0.26 & 1.23 & 1.12 & 4.64 & 2.99 & 0.118 & 0.85 \\
\hline & 1.83 & 0.53 & 1.25 & 0.71 & 0.94 & 0.46 & 1.04 & 0.73 & 0.76 & 0.68 & & \\
\hline \multirow[t]{2}{*}{ Consumption of $Y$} & 3.66 & 12.94 & 2.86 & 3.68 & 6.88 & 0.82 & 7.88 & 5.7 & 7.46 & 8.13 & 0.714 & 0.87 \\
\hline & 1.45 & 1.13 & 0.75 & 1.62 & 2.07 & 2.17 & 2.89 & 2.74 & 1.14 & 1.42 & & \\
\hline \multirow[t]{2}{*}{ Consumption of $\mathrm{Z}$} & 5.62 & 28.19 & 10.4 & 18.64 & 7.59 & 2.51 & 4.21 & 14.56 & 13.94 & 13.43 & 0.891 & 0.86 \\
\hline & 2.48 & 5.99 & 2.29 & 5.11 & 1.14 & 3.26 & 3.27 & 1.39 & 3.12 & 1.84 & & \\
\hline
\end{tabular}

Table 8: Convergence Regressions for Terms of Trade: TD environment vs. CU environment

\begin{tabular}{|c|c|c|c|c|c|c|c|c|c|c|c|c|}
\hline Variable & $\mathbf{B}_{11}$ & $\mathbf{B}_{12}$ & $\mathbf{B}_{13}$ & $\mathbf{B}_{14}$ & $\mathrm{C}_{11}$ & $\mathrm{C}_{12}$ & $\mathrm{C}_{13}$ & $\mathrm{C}_{14}$ & $\mathbf{B}_{2}$ & $\mathrm{C}_{2}$ & p-value & $\mathbf{R}^{2}$ \\
\hline \multirow[t]{2}{*}{$\mathrm{TOT}_{1}$} & 32.03 & 59.73 & 33.49 & 16.62 & 70.95 & 59.95 & 79.94 & 73.49 & 40.36 & 73.22 & 0.000 & 0.96 \\
\hline & 12.07 & 12.75 & 5.78 & 4.47 & 7.12 & 11.7 & 6.89 & 4.16 & 4.71 & 6.04 & & \\
\hline \multirow[t]{2}{*}{$\mathrm{TOT}_{2}$} & 59.04 & 38.23 & 42.83 & 50.49 & 55.94 & 119.89 & 140.58 & 151.92 & 41.01 & 128.997 & 0.000 & 0.94 \\
\hline & 5.77 & 8.71 & 9.62 & 5.39 & 23.63 & 26.46 & 14.82 & 20.43 & 6.53 & 14.87 & & \\
\hline \multirow[t]{2}{*}{$\mathrm{TOT}_{3}$} & 139.41 & 151.66 & 70.49 & 75.7 & 79.77 & 42.91 & 23.65 & 10.34 & 53.61 & 24.79 & 0.020 & 0.88 \\
\hline & 9.24 & 48.33 & 7.33 & 6.56 & 15.17 & 7.3 & 4.87 & 4.37 & 10.27 & 6.51 & & \\
\hline
\end{tabular}

Figure 6: Trade Diversion

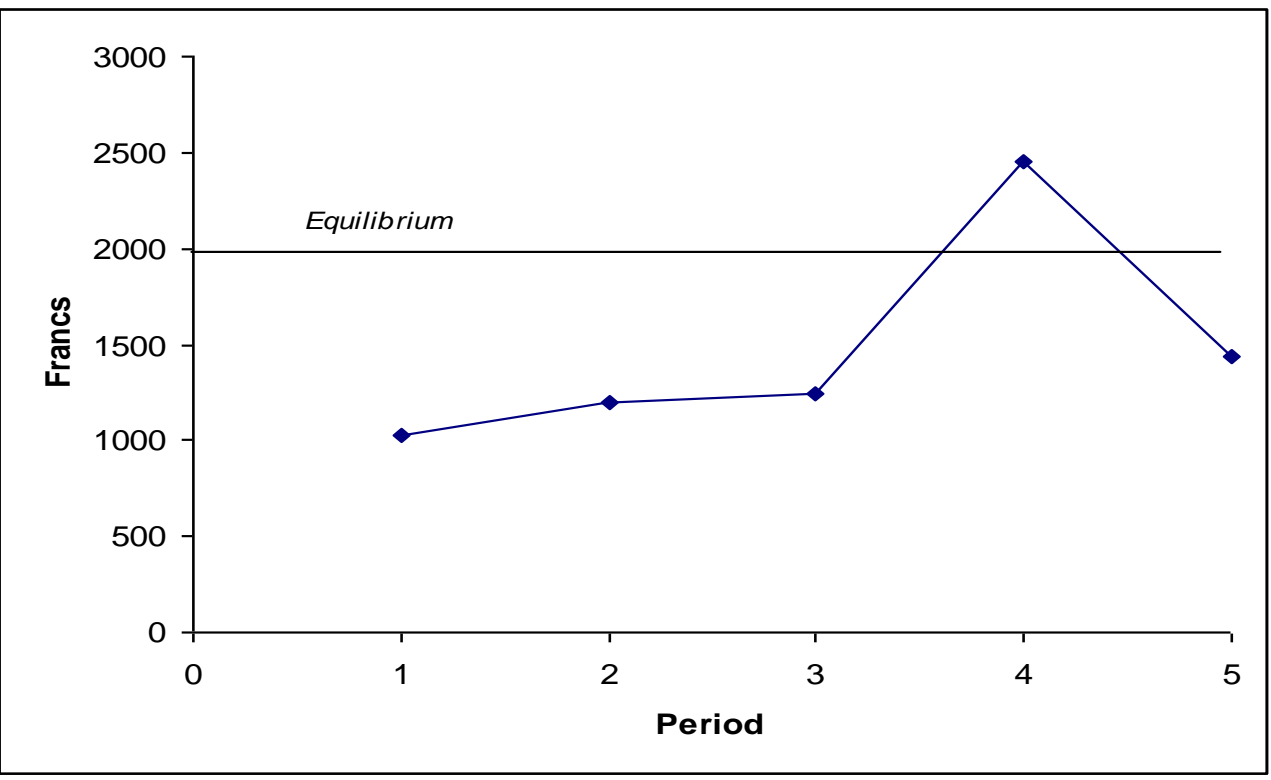


We apply the Ashenfelter-El-Gamal model check for convergence in trade diversion.

$$
A_{i t}=C_{11} D_{1}\left(\frac{1}{t}\right)+\ldots \ldots+C_{1 i} D_{i}\left(\frac{1}{t}\right)+\ldots . . C_{1 n} D_{n}\left(\frac{1}{t}\right)+C_{2}\left(\frac{t-1}{t}\right)+u_{i t}
$$

Table 9: Convergence Regression for Trade Diversion

\begin{tabular}{lll}
\hline $\mathrm{C}_{11}$ & -842.21 & 817.46 \\
$\mathrm{C}_{12}$ & 592.21 & 412.34 \\
$\mathrm{C}_{13}$ & 1994.5 & 445.68 \\
$\mathrm{C}_{14}$ & 1169.29 & 499.3 \\
$\mathrm{C}_{2}$ & 2078.56 & 399.22 \\
$\mathrm{P}$-value & $\mathrm{ns}$ & \\
$\mathrm{R}^{2}$ & 0.89 & \\
\hline
\end{tabular}

Table 9 suggests strong convergence. We fail to reject the null that the asymptote of our regression is similar to the equilibrium predicted trade diversion. Statistically, we show that the extreme comparative advantage country experiences trade diversion losses, consistent with Venables' (2003) theoretical model.

\section{Conclusion}

In this experiment a laboratory setting is constructed to induce a tariff distorted and CU trading environments within the $3 \times 3$ CRM . In the former, tariffs are imposed on goods in which each country specializes; in the CU, internal tariffs are eliminated between members and a common external tariff set on external imports. We use a convergence regression to compare the two environments and test several hypotheses. We found that a CU increases trade flows within the union and reduces trade flows outside it, increases member countries consumption of some goods and improves members' terms of trade. There is also trade diversion which is a loss to the extreme comparative advantage country. As far as we are aware this is the first test of core CU propositions using laboratory generated experimental data. Our results support both the theoretical argument and practical observation that creation of customs union tend to induce trade among members.

\section{References}

Brander, J. A. \& Spencer, B. J. (1985). Export Subsidies and International Market Share Rivalry. Journal of International Economics, 18, 83-100.

Chen, K. Y. \& Plott, C. R. (2002). Information Aggregation Mechanisms: Concept, Design and Implementation for a Sales Forecasting Problem. Social Science Working Paper 1131, California Institute of Technology

Engelman, D. \& Normann, H. T. (2003). An Experimental Test of Strategic Trade Policy. Center for Economic Research and Graduate Education, Working Paper, 212.

Goodfellow, J. \& Plott, C. R. (1990). An Experimental Examination of the Simultaneous Determination of Input Prices and Output Prices. Southern Economic Journal, 56, 969-983.

Jones, R. W. (1961). Comparative Advantage and the Theory of Tariffs: A Multi-Country, Multi-Commodity Model. Review of Economic Studies, 28, 161-175.

Lian, P. \& Plott, C. R. (1998). General Equilibrium, Markets, Macroeconomics and Money in a Laboratory Experimental Environment. Economic Theory, 12, 21-76.

Noussair, C. N., Plott, C. R. \& Riezman, R. G. (1995). An Experimental Investigation of the Patterns of International Trade. American Economic Review, 85, 462-491.

Noussair, C. N., Plott, C. R. \& Riezman, R. G. (2007). Production, Trade, Exchange Rates and Equilibration in Large Experimental Economies. European Economic Review, 51, 49-76.

Noussiar, C. N. \& Powell, O. (2008). Peak and Valleys: Experimental Asset Markets with Non-Monotonic Fundamentals. Discussion paper 2008-49, Tilburg University.

Nowbutsing, B. M. (2011). Fragility of Comparative in Higher Dimensions: An Experimental Investigation. Journal of Economics and Behavioural Studies, 2, 151-170.

Plott, C. R. (1991). A Computerized Laboratory Market System and Research Support Systems for the Multiple Unit Double Auction. Working Paper, 783, California Institute of Technology. 
Plott, C. R. \& Gray, P. (1990). The Multiple Unit Double Auction. Journal of Economic Behavior and Organization, 13, 245-258.

Venables, A. J. (2003). Winners and Losers from Regional Integration Agreements. Economic Journal, 113, 747- 761.

Viner, J. (1950). The Customs Union Issues, New York: Carnegie Endowment for International Peace.

\section{APPENDIX 1}

REDEMPTION VALUES

\begin{tabular}{|c|c|c|c|c|c|c|c|}
\hline Consumer 1 & Unit & X Unit & X Total & Y Unit & Y Total & Z Unit & Z Total \\
\hline & & Value & Value & Value & Value & Value & Value \\
\hline & 1 & 600 & 600 & 640 & 640 & 680 & 680 \\
\hline & 2 & 510 & 1110 & 550 & 1190 & 590 & 1270 \\
\hline & 3 & 420 & 1530 & 460 & 1650 & 500 & 1770 \\
\hline & 4 & 330 & 1860 & 370 & 2020 & 410 & 2180 \\
\hline & 5 & 240 & 2100 & 280 & 2300 & 320 & 2500 \\
\hline & 6 & 150 & 2250 & 190 & 2490 & 230 & 2730 \\
\hline & 7 & 60 & 2310 & 100 & 2590 & 140 & 2870 \\
\hline & 8 & 10 & 2320 & 10 & 2600 & 50 & 2920 \\
\hline \multirow[t]{10}{*}{ Consumer 2} & Unit & X Unit & X Total & Y Unit & Y Total & Z Unit & Z Total \\
\hline & & Value & Value & Value & Value & Value & Value \\
\hline & 1 & 555 & 555 & 595 & 595 & 635 & 635 \\
\hline & 2 & 465 & 1020 & 505 & 1100 & 545 & 1180 \\
\hline & 3 & 375 & 1395 & 415 & 1515 & 455 & 1635 \\
\hline & 4 & 285 & 1680 & 325 & 1840 & 365 & 2000 \\
\hline & 5 & 495 & 2175 & 235 & 2075 & 275 & 2275 \\
\hline & 6 & 105 & 2280 & 145 & 2220 & 185 & 2460 \\
\hline & 7 & 15 & 2295 & 55 & 2275 & 95 & 2555 \\
\hline & 8 & 5 & 2300 & 20 & 2295 & 50 & 2605 \\
\hline \multirow[t]{10}{*}{ Consumer 3} & Unit & X Unit & X Total & Y Unit & Y Total & Z Unit & Z Total \\
\hline & & Value & Value & Value & Value & Value & Value \\
\hline & 1 & 510 & 510 & 550 & 550 & 590 & 590 \\
\hline & 2 & 420 & 930 & 460 & 1010 & 500 & 1090 \\
\hline & 3 & 330 & 1260 & 370 & 1380 & 410 & 1500 \\
\hline & 4 & 240 & 1500 & 280 & 1660 & 320 & 1820 \\
\hline & 5 & 450 & 1950 & 190 & 1850 & 230 & 2050 \\
\hline & 6 & 60 & 2010 & 100 & 1950 & 140 & 2190 \\
\hline & 7 & 15 & 2025 & 10 & 1960 & 50 & 2240 \\
\hline & 8 & 5 & 2030 & 5 & 1965 & 10 & 2250 \\
\hline
\end{tabular}

\section{APPENDIX 2}

Instructions Type C -Tariff Distorted Environment: You are participating in an experiment of market decision making. The instructions are simple and if you follow them you can earn considerable amount of money which will be paid to you in cash. In this experiment, we are conducting a market in which you will be designated as one of two types of traders: Type $C$ or Type P. The experiment will run for 5 periods of 10 minutes each. You can find your type at the top of the instructions.

You are classified as Type $\mathrm{C}$ and you are given a Record Sheet for each period of the experiment and a Redemption value sheet (these are on your desk).

The Redemption Value Sheet will help you determine the value to you of any decision that you might make. This information is private to you and should not be revealed to anyone.

There are 4 types of goods (one input and three outputs) which can be traded in these markets: W, X, Y and Z. You can make profits in two ways: through consumption and trading of the goods. Unlike the 
practice session (practice 2) where you were allowed to buy and sell in the same market, here in each market you can either buy or sell but not both. When you move the order box between market you will see either F1-BUY if you are a buyer or F2-SELL if you are a seller.

Trading in all markets is in terms of francs; however your final payoff will be in terms of pounds. Your conversion rate is 3000 francs to $£ 1$ (for every 3000 francs profits you make, you earn $£ 1$ ). You will be paid at the end of the experiment according to how much profit you make. In this handout it is explained how to calculate profits.

ENDOWMENTS: At the beginning of each period, you will be given an endowment of W. This is the same for each period. You are free to sell any part of this endowment to anyone who might want to buy it.

At the beginning of the experiment you will receive 100000 francs cash on hand.

HOW THE SYSTEM WORKS: Type $C$ traders are endowed with $\mathrm{W}$ but would like to consume $\mathrm{X}, \mathrm{Y}$ and $\mathrm{Z}$. They can sell $\mathrm{W}$ to Type $\mathrm{P}$ to increase their cash in order to buy $\mathrm{X}, \mathrm{Y}$ and $\mathrm{Z}$. Thus, Type $\mathrm{C}$ is a seller in market for $\mathrm{W}$ and buyer in market for $\mathrm{X}, \mathrm{Y}$ and $\mathrm{Z}$.

Type $\mathrm{P}$ traders are also endowed with $\mathrm{W}$, but they may purchase units of $\mathrm{W}$ from Type $\mathrm{C}$ traders in order to produce. They can produce $\mathrm{X}, \mathrm{Y}, \mathrm{Z}$ from $\mathrm{W}$ and sell them to Type $\mathrm{C}$ traders to increase their cash on hand. Thus, Type $\mathrm{P}$ is a buyer in market for $\mathrm{W}$ and seller in market for $\mathrm{X}, \mathrm{Y}$ and $\mathrm{Z}$.

\section{SPECIFIC INSTRUCTIONS TO TYPE C}

CONSUMPTION: During the experiment you are free to sell as many units as you wish of $\mathrm{W}$ and buy as many units of $\mathrm{X}, \mathrm{Y}$ and $\mathrm{Z}$ as you wish. Each unit of $\mathrm{X}, \mathrm{Y}$ and $\mathrm{Z}$ you buy is assumed to be consumed by you.

Your Redemption Value sheet determines the amount you receive through consumption. You have already been instructed in how to read the redemption value sheet in the practice session. For the first unit of $\mathrm{X}$ that you consume for a given trading period, you receive the amount listed on your Redemption Value Sheet - the first row in the X unit value column (500, for example). For the second unit of X that you consume, you receive the amount listed in second row of the $\mathrm{X}$ unit value column ( 480 for example). The total amount that you receive from the consumption of both is found in the second column of $X$ total value column $(500+480=980)$. The amount you receive from consumption of $\mathrm{Y}$ and $\mathrm{Z}$ are found in a similar way by reading the final 4 columns. The redemption value you received from $\mathrm{W}$ is always zero.

Whenever you trade you should take account of those redemption values. Your per unit profit is given by: (redemption value- purchase price).

\section{Note: You are not allowed to produce: DO NOT HIT F4 AT ANYTIME.}

REDEMPTION VALUE SHEET- in francs (for Consumption Decisions)

\begin{tabular}{|c|c|c|c|c|}
\hline Wnit $\mathrm{X}$ & $\begin{array}{l}\text { Init X total Y uni } \\
\text { Jalue Value Val }\end{array}$ & Y total & $\begin{array}{l}\text { Z Unit } \\
\text { Value }\end{array}$ & $\begin{array}{l}\text { total } \\
\text { Value }\end{array}$ \\
\hline 5 & po 500 & & & \\
\hline 2 & $480 \quad 980$ & & & \\
\hline 3 & $\vec{r}$ & & & \\
\hline 4 & & & & \\
\hline 5 & & म2 & $2 \pi y$ & $\sqrt{14}$ \\
\hline
\end{tabular}




\section{INSTRUCTIONS TO BOTH TYPES}

TRADING PROFITS: You can earn profits through consumption and trading. Selling increases your cash on hand by the amount of total sales revenue. Buying decreases your cash in hand by the value of purchases.

EARNINGS: Your profits per period exactly is equal to

(Cash in hand at the end of the period) - (Cash in hand at the beginning of the period) + (Redemption value of units that you consume).

At the end of each period you must complete a record sheet.

\section{Record Sheet}

\section{Trading}

\section{Period No:}

(1) Cash on hand at end of the period

(2) Cash on hand at beginning of period

(3) Net Change in cash on hand (1) - (2)

\section{Consumption}

(4) Units Consumed: X

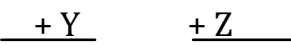

Earnings from consumption

(5) $X$

(6) $Y$

(7) $\mathrm{Z}$

(8) Total Earnings from consumption

$(5)+(6)+(7)$

\section{(10) TOTAL PROFITS FOR THE PERIOD: (3) + (8)}

Your record sheet is divided into two sections: Trading and Consumption. In line (1) fill the cash on hand at the end of the period. In line (2) fill the cash on hand at the beginning of the period. Line (3) is simply line (1) minus line (2). In line (4) enter the number of units that you consume of W, X, Y and Z. In line (5) (7), fill in the earnings from the consumption $X, Y$ and $Z$ and $Y$ based on your redemption values sheet. In line (8) add the total of lines (5), (6) and (7). In line (9) add the total of line (3) and (8), this is your profit for the period (in francs). You should aim to maximise your profits since this value will determines your earnings at the end of the experiment.

\section{MARKET RESTRICTIONS}

Some of you may not be able to trade in all markets. You may not trade in MARKET 10 and MARKET 12

You will be taxed for trading in market 1 and market 9. For each unit you buy in market 1 , you pay a tax of 160 francs. For each unit you buy in market 9, you pay a tax of 170 francs. The taxes remain the same for the entire experiment. 


\section{APPENDIX 3 \\ Instructions Type C- Customs Union Environment}

You are participating in an experiment of market decision making. The instructions are simple and if you follow them you can earn considerable amount of money which will be paid to you in cash. In this experiment, we are conducting a market in which you will be designated as one of two types of traders: Type $C$ or Type $P$. The experiment will run for 5 periods of 10 minutes each. You can find your type at the top of the instructions.

You are classified as Type $\mathrm{C}$ and you are given a Record Sheet for each period of the experiment and a Redemption value sheet (these are on your desk).

The Redemption Value Sheet will help you determine the value to you of any decision that you might make. This information is private to you and should not be revealed to anyone.

There are 4 types of goods (one input and three outputs) which can be traded in these markets: W, X, Y and Z. You can make profits in two ways: through consumption and trading of the goods. Unlike the practice session (practice 2) where you were allowed to buy and sell in the same market, here in each market you can either buy or sell but not both. When you move the order box between market you will see either F1-BUY if you are a buyer or F2-SELL if you are a seller.

Trading in all markets is in terms of francs; however your final payoff will be in terms of pounds. Your conversion rate is 3000 francs to $£ 1$ (for every 3000 francs profits you make, you earn $£ 1$ ). You will be paid at the end of the experiment according to how much profit you make. In this handout it is explained how to calculate profits.

\section{ENDOWMENTS}

At the beginning of each period, you will be given an endowment of $\mathrm{W}$. This is the same for each period. You are free to sell any part of this endowment to anyone who might want to buy it.

At the beginning of the experiment you will receive 100000 francs cash on hand.

\section{HOW THE SYSTEM WORKS}

Type $\mathrm{C}$ traders are endowed with $\mathrm{W}$ but would like to consume $\mathrm{X}$, $\mathrm{Y}$ and $\mathrm{Z}$. They can sell $\mathrm{W}$ to Type $\mathrm{P}$ to increase their cash in order to buy $\mathrm{X}, \mathrm{Y}$ and $\mathrm{Z}$. Thus, Type $\mathrm{C}$ is a seller in market for $\mathrm{W}$ and buyer in market for $\mathrm{X}, \mathrm{Y}$ and $\mathrm{Z}$.

Type P traders are also endowed with W, but they may purchase units of $\mathrm{W}$ from Type $\mathrm{C}$ traders in order to produce. They can produce $\mathrm{X}, \mathrm{Y}, \mathrm{Z}$ from $\mathrm{W}$ and sell them to Type $\mathrm{C}$ traders to increase their cash on hand. Thus, Type $\mathrm{P}$ is a buyer in market for $\mathrm{W}$ and seller in market for $\mathrm{X}, \mathrm{Y}$ and $\mathrm{Z}$.

\section{SPECIFIC INSTRUCTIONS TO TYPE C}

CONSUMPTION: During the experiment you are free to sell as many units as you wish of W and buy as many units of $\mathrm{X}, \mathrm{Y}$ and $\mathrm{Z}$ as you wish. Each unit of $\mathrm{X}, \mathrm{Y}$ and $\mathrm{Z}$ you buy is assumed to be consumed by you.

Your Redemption Value sheet determines the amount you receive through consumption. You have already been instructed in how to read the redemption value sheet in the practice session. For the first unit of $\mathrm{X}$ that you consume for a given trading period, you receive the amount listed on your Redemption Value Sheet - the first row in the X unit value column (500, for example). For the second unit of X that you consume, you receive the amount listed in second row of the $\mathrm{X}$ unit value column (480 for example). The total amount that you receive from the consumption of both is found in the second column of $X$ total value column $(500+480=980)$. The amount you receive from consumption of $\mathrm{Y}$ and $\mathrm{Z}$ are found in a similar way by reading the final 4 columns. The redemption value you received from $\mathrm{W}$ is always zero.

Whenever you trade you should take account of those redemption values. Your per unit profit is given by: (redemption value- purchase price). 
REDEMPTION VALUE SHEET - in francs (for Consumption Decisions)

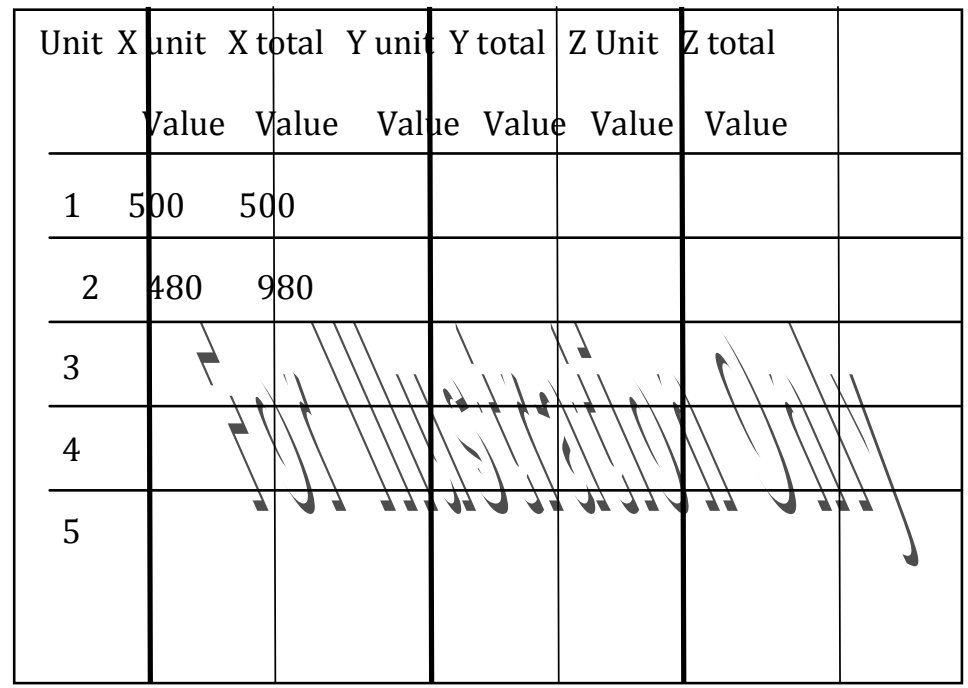

Note: You are not allowed to produce: DO NOT HIT F4 AT ANYTIME.

\section{INSTRUCTIONS TO BOTH TYPES}

TRADING PROFITS: You can earn profits through consumption and trading. Selling increases your cash on hand by the amount of total sales revenue. Buying decreases your cash in hand by the value of purchases.

\section{EARNINGS}

Your profits per period exactly is equal to

(Cash in hand at the end of the period) - (Cash in hand at the beginning of the period) + (Redemption value of units that you consume). At the end of each period you must complete a record sheet.

\section{Record Sheet}

\section{Trading}

Period No:

(1) Cash on hand at end of the period

(2) Cash on hand at beginning of period

(3) Net Change in cash on hand (1) - (2)

\section{Consumption}

(4) Units Consumed: X

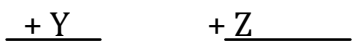

Earnings from consumption
(5) $X$
(6) $\mathrm{Y}$
(7) $\mathrm{Z}$
(8) Total Earnings from consumption
$(5)+(6)+(7)$

(10) TOTAL PROFITS FOR THE PERIOD: (3) + (8) 
Your record sheet is divided into two sections: Trading and Consumption. In line (1) fill the cash on hand at the end of the period. In line (2) fill the cash on hand at the beginning of the period. Line (3) is simply line (1) minus line (2). In line (4) enter the number of units that you consume of W, X, Y and Z. In line (5) (7), fill in the earnings from the consumption $\mathrm{X}, \mathrm{Y}$ and $\mathrm{Z}$ and $\mathrm{Y}$ based on your redemption values sheet. In line (8) add the total of lines (5), (6) and (7). In line (9) add the total of line (3) and (8), this is your profit for the period (in francs). You should aim to maximise your profits since this value will determines your earnings at the end of the experiment.

\section{MARKET RESTRICTIONS}

Some of you may not be able to trade in all markets. You may not trade in MARKET 10 and MARKET 12

You will be taxed for trading market 9 . For each unit you buy in market 9 , you pay a tax of 170 francs. The taxes remain the same for the entire experiment.

\section{TECHNICAL APPENDIX}

Tariff Distorted Predictions

Differentiating the utility function:

$U(X, Y, Z)=600 X-45 X^{2}+720 Y-45 Y^{2}+840 Z-45 Z^{2}+m$

gives the marginal utilities of each good, i.e.

$$
\begin{aligned}
& M U_{X}=\frac{\partial U}{\partial X}=600-90 X \\
& M U_{Y}=\frac{\partial U}{\partial Y}=720-90 Y \\
& M U_{Z}=\frac{\partial U}{\partial Z}=840-90 Z
\end{aligned}
$$

Given there are 3 consumers in country $i$, free trade aggregate demand in each country is given by:

$$
\begin{aligned}
& A D^{i}(X)=P_{X}^{*}=600-30 X \\
& A D^{i}(Y)=P_{Y}^{*}=720-30 Y \\
& A D^{i}(Z)=P_{Z}^{*}=840-30 Z
\end{aligned}
$$

where $\mathrm{i}=1,2,3$

Since, there are 9 consumers in the whole system, total aggregate demand is given by:

$$
\begin{aligned}
& A D(X)=P_{X}^{*}=600-10 X \\
& A D(Y)=P_{Y}^{*}=720-10 Y \\
& A D(Z)=P_{Z}^{*}=840-10 Z
\end{aligned}
$$

\section{Production \\ $\mathrm{X}=4(9)=36$ \\ $\mathrm{Y}=3(12)=36$ \\ $\mathrm{Z}=3(15)=45$}

Since total production = total consumption; replacing production levels in equation (4) yields free trade prices, such that $\mathrm{P}_{\mathrm{X}}^{*}=240 ; \mathrm{P}^{*}{ }_{\mathrm{Y}}=360$ and $\mathrm{P}_{\mathrm{Z}}^{*}=390$.

The introduction of the tariff causes a divergence in consumption level between the importing and exporting country. 


\section{Country 1}

The introduction of $T_{i} j(i=X, Y$ and $Z ; j=1,2,3$ ) increases the consumption of good $X$ and decreases consumption of Good $\mathrm{Y}$ and $\mathrm{Z}$. New demand functions in each country can be written as:

$\mathrm{P}^{*} \mathrm{x}-1 / 2\left(\mathrm{~T}_{\mathrm{X}}^{2}+\mathrm{T}_{\mathrm{x}}^{3}\right)=600-30 \mathrm{X}$

$\mathrm{P}^{*} \mathrm{Y}+\mathrm{T}_{\mathrm{Y}^{1}} / 2=720-30 \mathrm{Y}$

$\mathrm{P}_{\mathrm{Z}}^{*}+\mathrm{T}_{\mathrm{Z}}{ }^{1} / 2=840-30 \mathrm{Z}$

As countries maximizes the same utility function, this implies that, i.e. $T_{i}{ }^{j}=T_{i}$. Substituting free trade prices, gives quantity demanded:

$$
\begin{aligned}
& \mathrm{X}=12+\mathrm{T}_{\mathrm{X}} / 30 \\
& \mathrm{Y}=12-\mathrm{T}_{\mathrm{Y}} / 60 \\
& \mathrm{Z}=15-\mathrm{T}_{\mathrm{Z}} / 60
\end{aligned}
$$

We can write preferences as a function of $T_{i}$

$$
\begin{aligned}
\mathrm{U}^{1} & =5355-16 \mathrm{~T}_{\mathrm{X}}-0.05 \mathrm{~T}^{2} \mathrm{X}+6 \mathrm{~T}_{\mathrm{Y}}-0.0125 \mathrm{~T}^{2} \mathrm{Y}+8.5 \mathrm{~T}_{\mathrm{Z}}-0.0125 \mathrm{~T}^{2} \mathrm{Z} \\
& =\mathrm{U}^{\mathrm{F}}-16 \mathrm{~T}_{\mathrm{X}}-0.05 \mathrm{~T}^{2} \mathrm{X}+6 \mathrm{~T}_{\mathrm{Y}}-0.0125 \mathrm{~T}^{2} \mathrm{Y}+8.5 \mathrm{~T}_{\mathrm{Z}}-0.0125 \mathrm{~T}^{2} \mathrm{Z}
\end{aligned}
$$

where $U^{F}$ denotes free trade utility level.

\section{Country 2}

The introduction of $\mathrm{T}_{\mathrm{i}}(\mathrm{i}=\mathrm{X}, \mathrm{Y}$ and $\mathrm{Z}$ ) increases the consumption of good $\mathrm{Y}$ and decreases the consumption of Good X and Z. New demand functions are now:

$\mathrm{P}_{\mathrm{X}}^{*}+\mathrm{T}_{\mathrm{X}}^{2} / 2=600-30 \mathrm{X}$

$\mathrm{P}^{*}{ }_{\mathrm{Y}-}^{1 / 2}\left(\mathrm{~T}_{\mathrm{Y}}{ }^{1+}+\mathrm{T}_{\mathrm{Y}}{ }^{3}\right)=720-30 \mathrm{Y}$

$\mathrm{P}_{\mathrm{Z}+\mathrm{T}_{\mathrm{Z}}}^{*} / 2=840-30 \mathrm{Z}$

Substituting the free trade prices, $\mathrm{P}^{*}{ }_{\mathrm{X}}=360 ; \mathrm{P}^{*}{ }_{\mathrm{Y}}=240$ and $\mathrm{P}_{\mathrm{Z}}^{*}=390$ gives quantity demanded:

$$
\begin{aligned}
& \mathrm{X}=12-\mathrm{T}_{\mathrm{X}} / 60 \\
& \mathrm{Y}=12+\mathrm{T}_{\mathrm{Y}} / 30 \\
& \mathrm{Z}=15-\mathrm{T}_{\mathrm{Z}} / 60
\end{aligned}
$$

We can write preferences as a function of $\mathrm{T}_{\mathrm{i}}$, i.e.

$$
\begin{aligned}
\mathrm{U}^{2} & =5355+8 \mathrm{~T}_{\mathrm{X}}-0.0125 \mathrm{~T}^{2} \mathrm{X}-12 \mathrm{~T}_{\mathrm{Y}}-0.05 \mathrm{~T}^{2} \mathrm{Y}+8.5 \mathrm{~T}_{\mathrm{Z}}-0.0125 \mathrm{~T}^{2} \mathrm{Z} \\
& =\mathrm{U}^{\mathrm{F}}+8 \mathrm{~T}_{\mathrm{X}}-0.0125 \mathrm{~T}^{2} \mathrm{X}-12 \mathrm{~T}_{\mathrm{Y}}-0.05 \mathrm{~T}^{2} \mathrm{Y}+8.5 \mathrm{~T}_{\mathrm{Z}}-0.0125 \mathrm{~T}^{2} \mathrm{Z}
\end{aligned}
$$

\section{Country 3}

The introduction of $\mathrm{T}_{\mathrm{i}}(\mathrm{i}=\mathrm{X}, \mathrm{Y}$ and $\mathrm{Z})$ increases the consumption of good $\mathrm{Z}$ and decreases the consumption of Good X and Y. New demand functions are now:

$\mathrm{P}_{\mathrm{X}}^{*}+\mathrm{T}_{\mathrm{X}}^{3} / 2=600-30 \mathrm{X}$

$\mathrm{P}^{*}+\mathrm{T}^{3} / 2=720-30 \mathrm{Y}$

$\mathrm{P}_{\mathrm{Z}-1 / 2}^{*}\left(\mathrm{~T}_{\mathrm{Z}}{ }^{1}+\mathrm{T}_{\mathrm{Z}}{ }^{3}\right)=840-30 \mathrm{Z}$

Substituting the free trade prices, $\mathrm{P}^{*}{ }_{\mathrm{X}}=360 ; \mathrm{P}^{*}{ }_{\mathrm{Y}}=240$ and $\mathrm{P}_{\mathrm{Z}}^{*}=390$ gives quantity demanded:

$$
\begin{aligned}
& \mathrm{X}=12-\mathrm{T}_{\mathrm{X}} / 60 \\
& \mathrm{Y}=12-\mathrm{T}_{\mathrm{Y}} / 60 \\
& \mathrm{Z}=15+\mathrm{T}_{\mathrm{Z}} / 30
\end{aligned}
$$

We can write preferences as a function of $\mathrm{T}_{\mathrm{i}}$, i.e.

$$
\begin{aligned}
\mathrm{U}^{3} & =5355+8 \mathrm{~T}_{\mathrm{X}}-0.0125 \mathrm{~T}^{2} \mathrm{X}+6 \mathrm{~T}_{\mathrm{Y}}-0.0125 \mathrm{~T}^{2} \mathrm{Y}-17 \mathrm{~T}_{\mathrm{Z}}-0.05 \mathrm{~T}^{2} \mathrm{Z} \\
& =\mathrm{U}^{\mathrm{F}}+8 \mathrm{~T}_{\mathrm{X}}-0.0125 \mathrm{~T}^{2} \mathrm{X}+6 \mathrm{~T}_{\mathrm{Y}}-0.0125 \mathrm{~T}^{2} \mathrm{Y}-17 \mathrm{~T}_{\mathrm{Z}}-0.05 \mathrm{~T}^{2} \mathrm{Z}
\end{aligned}
$$

Differentiating equation (7), (10) and (13) gives the tariff level on each good: 
$\mathrm{dU}^{1} / \mathrm{dT}_{\mathrm{Y}}=\mathrm{dU}^{3} / \mathrm{dT}_{\mathrm{Y}}=0 \Rightarrow \mathrm{T}_{\mathrm{Y}}=240$

$\mathrm{dU}^{1} / \mathrm{dT}_{\mathrm{Z}}=\mathrm{dU}^{2} / \mathrm{dT}_{\mathrm{Z}}=0 \Rightarrow \mathrm{T}_{\mathrm{Z}}=340$

$\mathrm{dU}^{2} / \mathrm{dT}_{\mathrm{X}}=\mathrm{dU}^{3} / \mathrm{dT}_{\mathrm{X}}=0 \Rightarrow \mathrm{T}_{\mathrm{X}}=320$

Therefore, $\mathrm{T}_{\mathrm{X}}=320 ; \mathrm{T}_{\mathrm{Y}}=240$ and $\mathrm{T}_{\mathrm{Z}}=340$

Substituting these tariff level in equation (6), (9) and (12) gives the quantity demanded of $\mathrm{X}, \mathrm{Y}$ and $\mathrm{Z}$ in each country after the introduction of the tariffs. Both demands and tariffs are substituted in equations (5), (8) and (11) to calculate the tariff distorted prices. The relationship whereby input prices equal their marginal revenue product still holds. We also compute a weighted average terms of trade for each country.

\section{Customs Union Predictions}

Following the creation of the customs union between country 1 and country 2 , tariffs are eliminated on internal trade and imports of $\mathrm{Z}$ from country 3 are taxed at the same rate as in the TD environment.

Given there are 6 consumers in the customs union, aggregate demand of $\mathrm{X}$ and $\mathrm{Y}$ in the customs union is:

$$
\begin{aligned}
& A D^{C U}(X)=P_{X}^{C U}=600-15 X \\
& A D^{C U}(Y)=P_{Y}^{C U}=720-15 Y
\end{aligned}
$$

Quantity demanded in country 3 is the same as the tariff distorted situation, i.e. 6.66 units, 8 units and 26.33 units of good $\mathrm{X}, \mathrm{Y}$ and $\mathrm{Z}$ respectively.

Since production of $\mathrm{X}$ and $\mathrm{Y}$ are 36 and 36 units respectively, $\mathrm{CU}$ consumption of $\mathrm{X}$ and $\mathrm{Y}$ are 29.333 units and 28 units respectively which can be substituted in equation 14 to give $\mathrm{P}_{\mathrm{X}}^{\mathrm{CU}}=160 ; \mathrm{P}_{\mathrm{Y}}^{\mathrm{CU}}=300$.

\section{Country 1}

Following the creation of the customs union, new demand curves are

$\mathrm{P}_{\mathrm{X}-1 / 2}^{*} \mathrm{~T}_{\mathrm{x}}{ }^{3}=600-30 \mathrm{X}$

$\mathrm{P}^{*} \mathrm{Y}=720-30 \mathrm{Y}$

$\mathrm{P}^{*} \mathrm{Z}+1 / 2 \mathrm{~T}_{\mathrm{Z}}{ }^{*}=840-30 \mathrm{Z}$

New quantities demanded are:

$$
\begin{aligned}
& \mathrm{X}=12+\mathrm{T}^{3} \mathrm{x} / 60 \\
& \mathrm{Y}=12 \\
& \mathrm{Z}=15-\mathrm{T}_{\mathrm{Z}} / 60
\end{aligned}
$$

At $\mathrm{T}^{3} \mathrm{X}=320$ and $\mathrm{T}^{\mathrm{CET}}=340$; new quantity demanded of $\mathrm{X}, \mathrm{Y}$ and $\mathrm{Z}$ are 17.33, 12, 9.33 units.

\section{Country 2}

New demand functions are now:

$\mathrm{P}^{*}{ }_{\mathrm{X}}=600-30 \mathrm{X}$

$\mathrm{P}^{*}{ }_{\mathrm{Y}-1 / 2 \mathrm{~T}^{3}}=720-30 \mathrm{Y}$

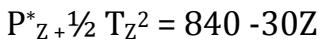

New quantities demanded are:

$\mathrm{X}=12$

$\mathrm{Y}=12+\mathrm{T}^{3} \mathrm{Y} / 60$

$\mathrm{Z}=15-\mathrm{T}_{\mathrm{Z}} / 60$

At $\mathrm{T}^{2} \mathrm{Y}=240$ and $\mathrm{T}^{\mathrm{CET}}=340$; new quantity demanded of $\mathrm{X}, \mathrm{Y}$ and $\mathrm{Z}$ are 12, 16, 9.33 units.

\section{Trade Diversion}

Following the creation of the $\mathrm{CU}$, country 1 buys good $\mathrm{Z}$ from country 2 rather than country 3 . This is trade diversion and country 1 pays an additional costs of $\left(\mathrm{P}_{\mathrm{L} 2} \mathrm{a}^{2} \mathrm{LZ}-\mathrm{P}_{\mathrm{Z}}{ }^{*}\right) \mathrm{Z}_{\mathrm{m}}$. The equilibrium trade diversion in our model is 2145.9 francs per period and 42918 francs for the whole experiment. 